\title{
Analysis and Assessment of the Usefulness of Recycled Plastic Materials for the Production of Airfield Geocell
}

\author{
Mariusz Wesołowski *(D), Piotr Włodarski, Paweł Iwanowski $\mathbb{D}$ and Agata Kowalewska (D) \\ Air Force Institute of Technology, Airfield Division, ul. Ks. Bolesława 6, 01-494 Warsaw, Poland; \\ piotr.wlodarski@itwl.pl (P.W.); pawel.iwanowski@itwl.pl (P.I.); agata.kowalewska@itwl.pl (A.K.) \\ * Correspondence: mariusz.wesolowski@itwl.pl; Tel.: +48-261-851-324
}

Citation: Wesołowski, M.;

Włodarski, P.; Iwanowski, P.;

Kowalewska, A. Analysis and Assessment of the Usefulness of Recycled Plastic Materials for the Production of Airfield Geocell. Materials 2021, 14, 3557. https:// doi.org/10.3390/ma14133557

Academic Editor: Pavel Lukáč

Received: 31 May 2021

Accepted: 21 June 2021

Published: 25 June 2021

Publisher's Note: MDPI stays neutral with regard to jurisdictional claims in published maps and institutional affiliations.

\begin{abstract}
The load-bearing capacity of natural airfield pavement has a direct impact on the safety of air operations. Unfortunately, the field tests often indicate that the load-bearing capacity of natural airfield pavements is not sufficient. In this case, it is necessary to reinforce them in order to meet the requirements set out in international documents. It is important that the method of reinforcing the subsoil is fast and as noninvasively as possible. There are many methods of reinforcing the subsoil, however, they are expensive and time-demanding, which involves turning off the airport for a long time. Airfield geocells made of recycled plastics discussed in the article seem to be the optimal solution due to the quick implementation of their application by pressing into the existing natural pavement. The article presents the results of laboratory tests demonstrating that material in question is load-resistant and chemical-resistant, while field studies have confirmed that the airfield geocell made of the plastic in question improves the load carrying capacity of natural airfield pavement.
\end{abstract}

Keywords: plastics; recycling; natural airfield pavement; safety of air operations

\section{Introduction \\ 1.1. Overview}

All over the world, aviation infrastructure is extensive on a huge scale, including civil, military, aeroclub, exclusive use, airstrikes and helicopters. Each of these facilities must meet specific requirements regarding the condition of the airfield pavement, which has a direct impact on the safety of air operations [1].

Airfield pavement is any type of adequately prepared pavement on which aircraft can move [2]. Depending on the needs and type of airport functional element, the following types of airfield pavements are distinguished:

- Rigid pavements;

- Flexible pavements;

- Semi-rigid pavements;

- Natural pavements.

This article dealt with the issue of natural airfield pavement. Natural airfield pavement occurs as ground and turf. They are prepared by a properly made ground substrate, which ensures the safe movement of the aircraft without damaging its design. On aerodrome facilities with artificial pavement intended for air operations, natural pavement may occur on the following airport functional elements:

- Runway shoulders;

- Runway end safety areas (RESA).

Runway shoulders shall be prepared or constructed in such a way that, in the event of the aircraft being run off the runway, they can carry the weight of the aircraft without damaging the aircraft structure and that they can carry the weight of ground vehicles which may move on the side of the road [3]. The runway end safety areas should be prepared or constructed in such a way as to minimise the risk of damage to aircraft that 
has touched down in front of the runway or off the runway, to increase the possibility of braking the aircraft and to allow the movement of rescue and fire-fighting vehicles [3]. The most important parameter characterizing the natural airfield pavement is its load carrying capacity, which is determined by the California Bearing Ratio CBR. According to [4] the California Bearing Ratio is the percentage of force needed to push the standardized piston into the test ground to a certain depth compared to the force needed to push the piston to the same depth in the standardized soil sample. The load capacity of the natural aerodromes is, according to [5], the ability of the pavement to carry a specific load from an aircraft without risk of damage.

Previous studies by the authors of this article show that the load bearing capacity of natural airfield pavement often does not meet certain requirements, which can be a direct result of a plane crash. This was the case on 17 July 2007, when an Airbus A320-233 veered off the runway at Congonhas Airport (Brazil) and hit a petrol station and a building. In this case, 187 people were killed, including the crew. In another case recorded on 22 May 2010 a Boeing 737-800 plane crash landed in severe weather conditions. The plane did not stop on the runway, slid into the valley and went up in flames-158 people died [6].

In order to improve the load capacity of natural airfield pavements, different methods of reinforcing the ground substrate are used [7].

The article will describe a method of reinforcing natural airfield pavements with an airfield geocell made of recycled plastic materials.

\subsection{Overview of Existing Solutions}

Airfield geocells can be classified as geosynthetics in a very general way; they are largely used to strengthen the subsoil. Geosynthetic, according to [8], is a general term for which at least one component is made of synthetic or natural polymer, in the form of a sheet, tape or spatial form, used in contact with land and/or other materials in geotechnicals and construction. An example may be the case described in the article [9], which involved the use of a two-way reinforced composite foundation made of a mattress reinforced with geocells and gravel piles. According to the American Association for Research and Materials [10], geosynthetics are flat products made of polymeric material, used with soil, rocks or other materials related to geotechnical engineering as an integral part of a design, structure or system. However, the element (airfield geocell) that is the subject of this article does not appear in the geosynthetics qualification according to [8], but due to its function and composition it can be classified as a group of geosynthetics.

According to the PN-EN ISO 10318: 2007 [8] standard, geosynthetics are divided into geotextiles, geotextile related products, geosynthetic barriers and geocomposites. Each type of geosynthetics has its own application, including reinforcement weak subsoil, securing slopes against erosion, and as separation and drainage layers. These geosynthetics are part of the pavement structure. It is connected with the necessity to reconstruct the existing pavement and use a geosynthetic in accordance with the design of the structure of the layers of the structure. This entails the need to shut down the airport for a longer period of time. The main advantage of using airfield geocells made of plastic is the ability to quickly restore the operational capacity of the airport because they are rolled directly into the existing natural pavement.

The authors of [11], which describe the possibilities of reinforcement of ground routes in wet conditions, geocells (such as in this work) have been classified as Geo-Others-Turf Reinforcement (Figure 1). Geo-Others are described in [11] as reinforcements made of recycled plastics designed to protect the turf from rut formation, against soil erosion and to support turf compaction. In [12], the author describes geosynthetics as part of the group of geo-others that geocells also qualify for [13]. 


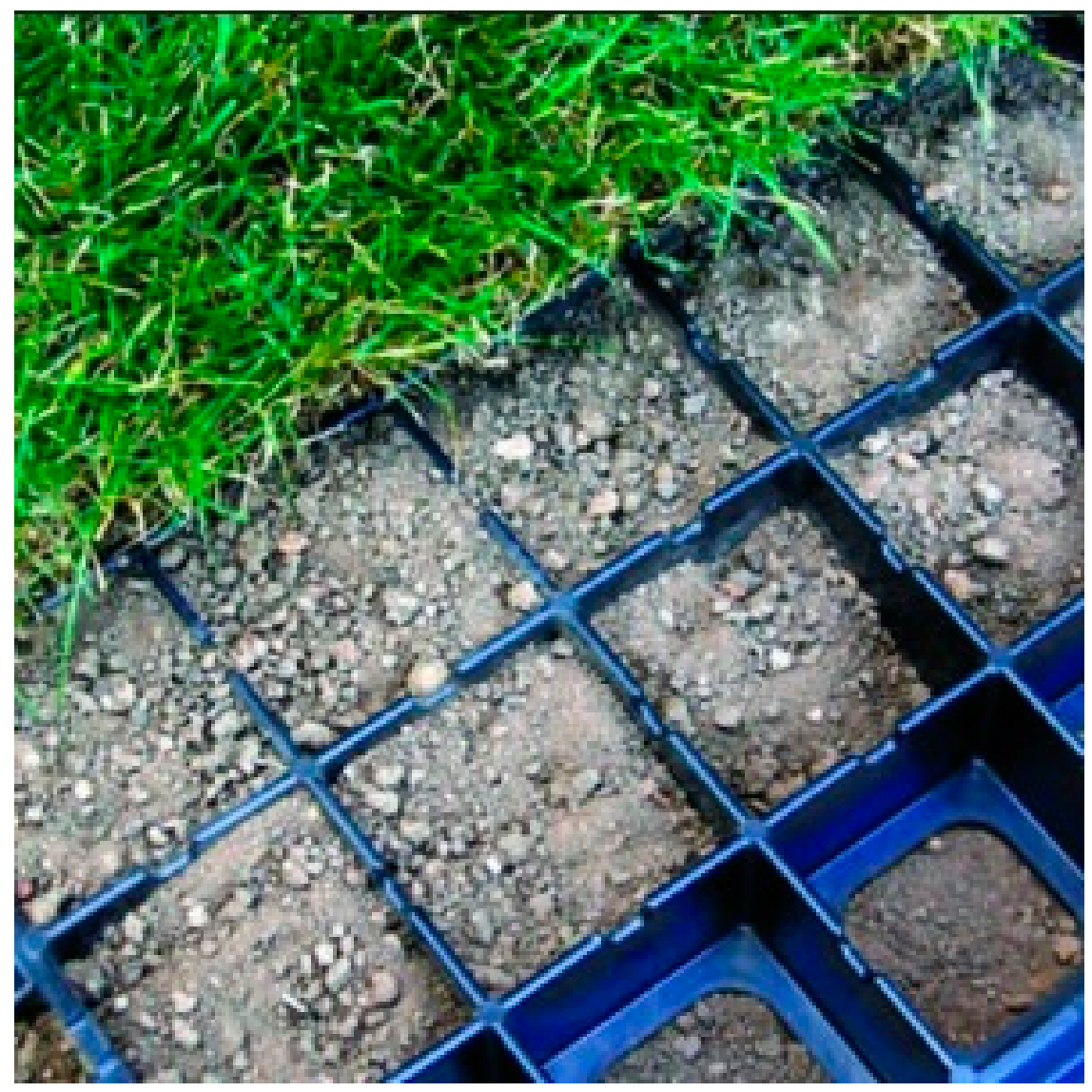

Figure 1. GEOBLOCK ${ }^{\circledR}$ Grass Pavers.

In [14], the authors presented the results of studies on the effect of the use of reinforcement of verges of unpaved cellular geosynthetics on vegetation growth. During the test period, it was not noticed that the geocells limited the growth of vegetation. Various combinations of substructure and the topsoil layer were studied, which turned out to have a significant impact on vegetation growth during observation.

The main group of raw materials from which the airfield geocell discussed in the article is produced comes from recycled plastic material.

In national and foreign literature, you can read many studies that describe laboratory experiments involving the use of cellular geogrid in load-bearing structural layers. The article [15] describes a series of static and cyclic plate load tests performed by a research team at the University of Kansas on geocell-reinforced primers with various filling materials, i.e., poorly sorted sand from the Kansas River, quarry waste and recycled asphalt pavement. Studies have shown that the geocell used to strengthen the substructures increased the load carrying capacity and rigidity of the substrates, reduced permanent deformation, reduced vertical stresses. The use of cellular geogrid has also affected the possibility of reducing the required thickness of the substructure to achieve the same parameters as the road on weak ground [15].

Geocells are used successfully as reinforcement for road and airfield pavement structural layers. The article [16] presents results that confirmed that the use of cellular restraining systems in the road substructure layer allowed for a reduction in the thickness of structural layers by up to $50 \%$ compared to the road without the use of geocell armament. The use of plastic geocells as reinforcement of structural layers or existing natural pavement makes it possible to use local filling materials, which generates economic (reduced investment costs) and environmental conditions due to reduced earthworks, which in turn reduces fuel consumption, pollution from vehicles [16]. 
Companies involved in the production of road geocells, which are used on access roads or parking lots, are increasingly developing new geogrid technologies that they use to strengthen natural airfield pavements. Novus HM proposes to strengthen the airport's grassy pavement by using the TERRA-GRID ${ }^{\circledR} \mathrm{E} 35$ (Figure 2) geocell [17]. It is a product made of plastic polyethylene (PE)/polypropylene (PP), which provides a load capacity of up to $160 \mathrm{t} / \mathrm{m}^{2}$ (depending on ground conditions and soil preparation). Novus HM declares that the TERRA-GRID ${ }^{\circledR}$ E 35 geocell is resistant to UV radiation, frost, oils, solvents, salt and most acids.

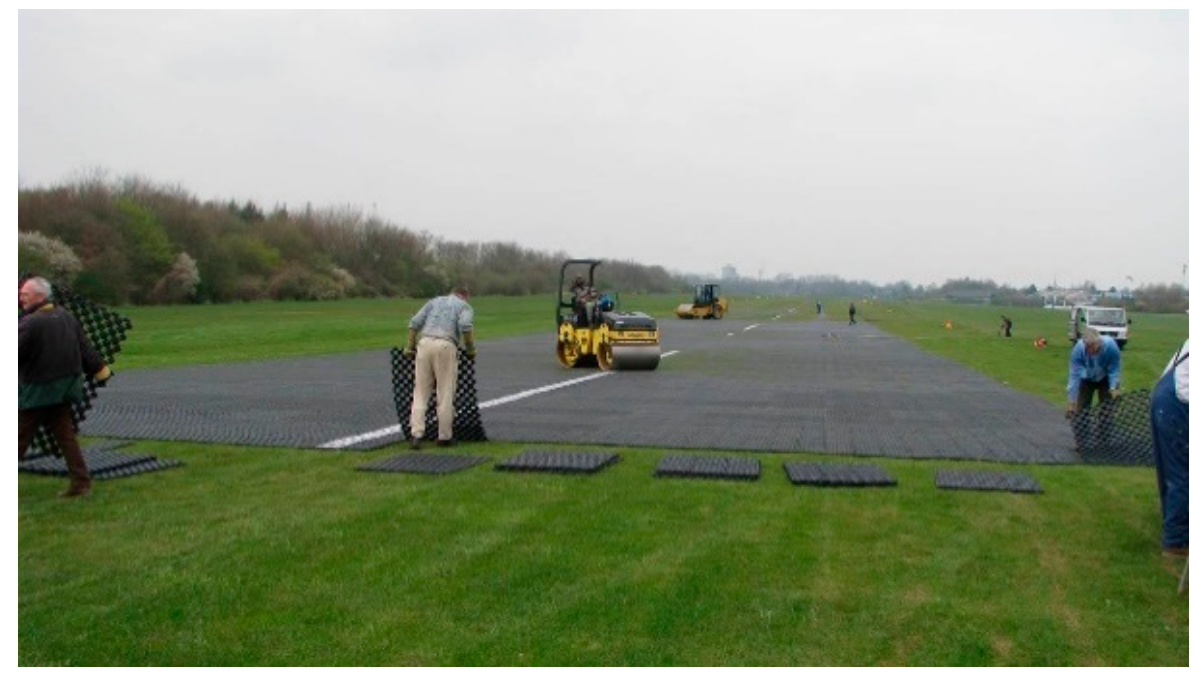

Figure 2. Solution made by the company Novus HM.

PERFO has developed a ground reinforcement system in the form of geocells for reinforcing various pavements, including grassy airfield pavements (Figure 3). The PERFO geocell is made of plastic polyethylene (PE)/polypropylene (PP), which provides a load capacity of about 60 tons $/ \mathrm{m}^{2}$ (depending on ground conditions and substrate preparation). PERFO geocells have been successfully used at many airport facilities to increase the safety of air operations [18].

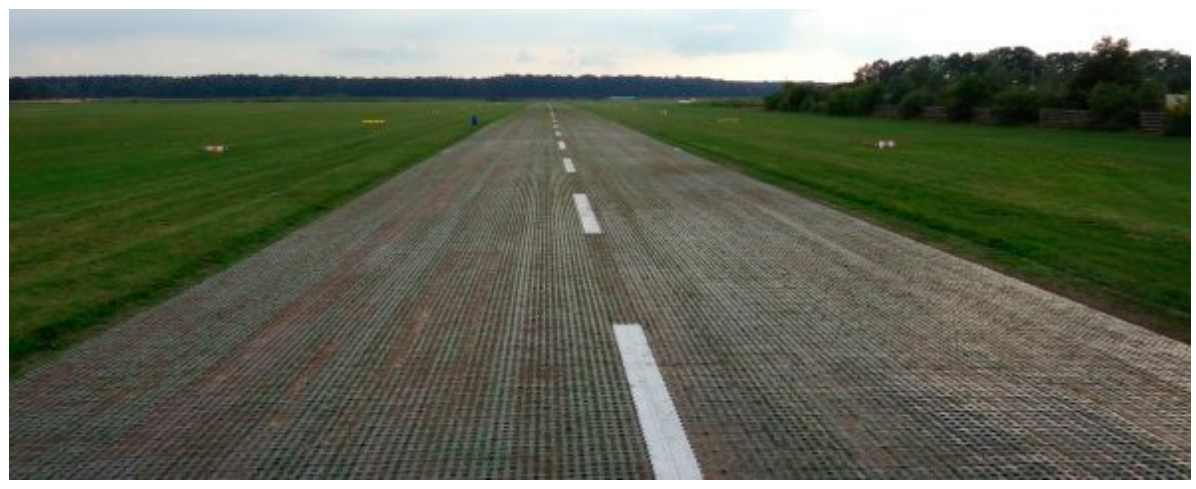

Figure 3. Solution made by the company PERFO.

Narew Airport 2 in Poland has a runway with grass pavement paved with geocells made of plastic and a length of $1500 \mathrm{~m}$ (Figure 4). Of the runway built in this technology, the runway in Narew is the longest runway in the world built with geogrid technology [19]. 


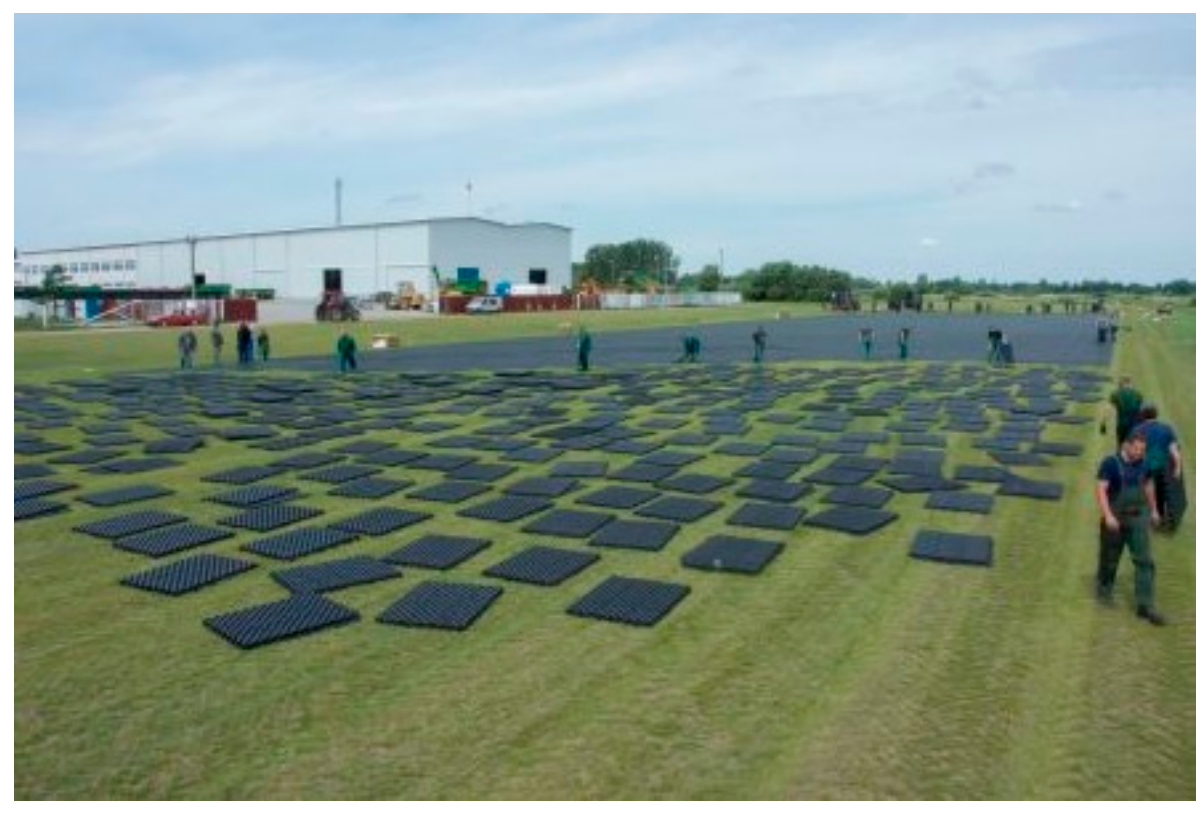

Figure 4. Laying the geocell on the natural pavement of the runway.

\subsection{Recycled Plastic Material as Airfield Geocell Material}

Structural plastics, e.g., polyethylene, polypropylene and polycarbonate, are used in various areas of life [20], such as engineering, electronics or electrical engineering, mainly due to their excellent thermal stability and high heat deformation temperatures [21].

This airfield geocell was formed by injection method of polyethylene and polypropylene obtained from the recycling process of plastic waste.

Polyethylene (PE) is an ethylene polymer with a repeatable structural unit of the main chain $\left[\mathrm{CH}_{2}-\mathrm{CH}_{2}\right]$ [20]. Polyethylene, depending on the conditions under which polymerization takes place, is divided into:

- High-pressure polyethylene-low density (e.g., LDPE);

- Low-pressure polyethylene-high density (e.g., HDPE).

Low-density polyethylene-high pressure (LDPE) is obtained from ethylene in the gas phase at a pressure of $180-250 \mathrm{MPa}$ and at a temperature of $200-250{ }^{\circ} \mathrm{C}$ [22]. The density of high-pressure polyethylene is between 0.90 and $0.94 \mathrm{~g} / \mathrm{cm}^{3}$ [23].

High density polyethylene (HDPE) is formed during a liquid phase polymerization reaction at $50-70{ }^{\circ} \mathrm{C}$ [22]. Chemically, it is closest to pure polyethylene (Figure 5). The density of low-pressure polyethylene is approximately $0.94-0.97 \mathrm{~g} / \mathrm{cm}^{3}$ [23].<smiles>CCCCCC(C)(C)CCCC</smiles>

Figure 5. Structural formula of pure polyethylene.

Polypropylene is formed by polymerization of propylene [24]. Polymerization of polypropylene is usually carried out in a solution at a temperature of $50{ }^{\circ} \mathrm{C}$ to $100{ }^{\circ} \mathrm{C}$. Polypropylene is one of the lightest plastics, with a density between 0.85 and $0.92 \mathrm{~g} / \mathrm{cm}^{3}$ [22]. 


\subsection{Injection Method of Forming Finished Products from Recycled Plastic Waste}

The growing demand for plastics requires the development of new technologies for their manufacture, processing and modification. Among the processing methods of thermoplastics, the injection process is a popular method [25]. Injection formatting is a leading technique for producing complex polymer elements. Demanding designs of plastic products, high quality requirements and time constraints force the optimisation of various input parameters crucial for achieving the desired quality indicators [26].

Plastic injection is a cyclic process of manufacturing polymer products, which involves melting the plastic, most often granules, and then being fed through the nozzle into the mould cavity. In pressurised form, the material enters a solid state and is removed as a finished product [27]. The diagram of the automated injection socket and the injection moulding machine construction diagram are shown in Figures 6 and 7 [28].

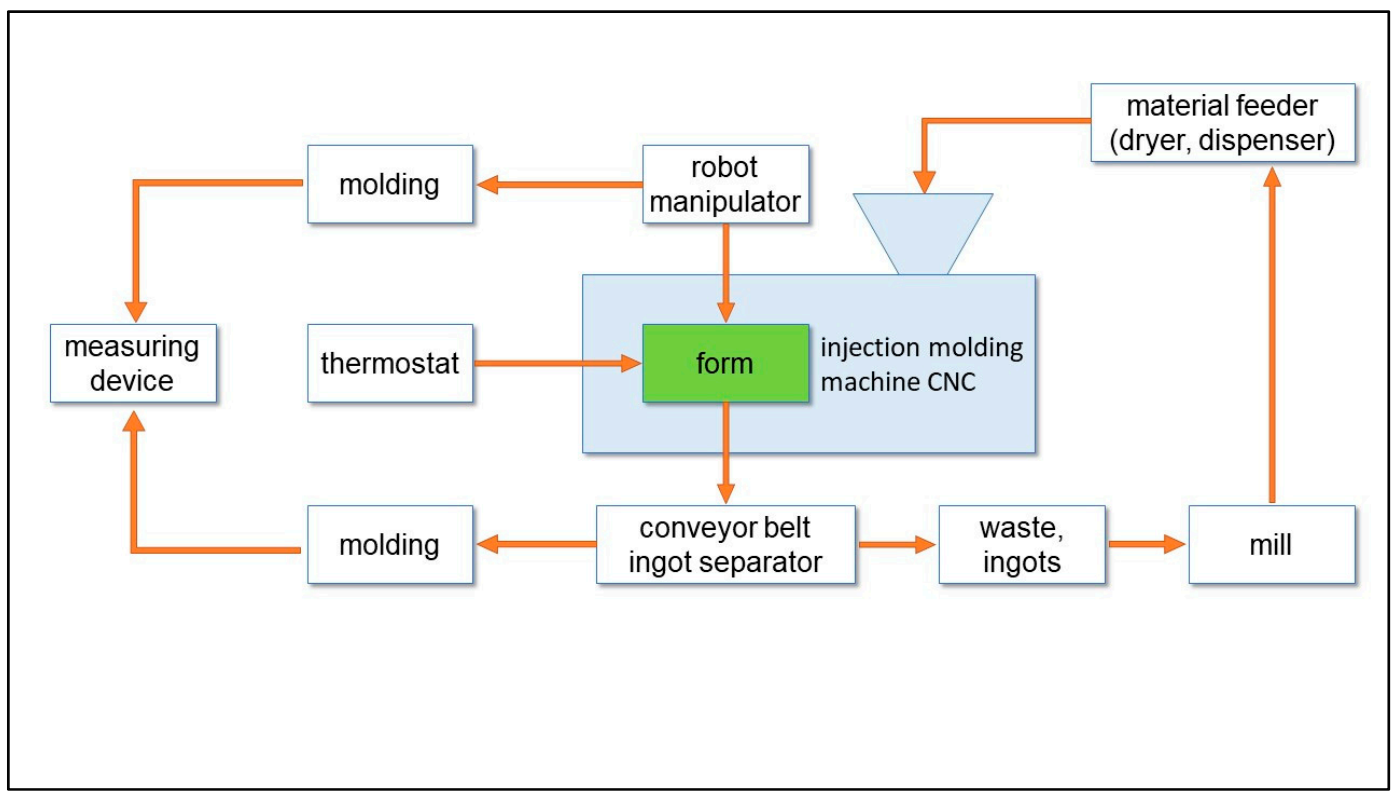

Figure 6. Automated production cell of injection moulding machine.

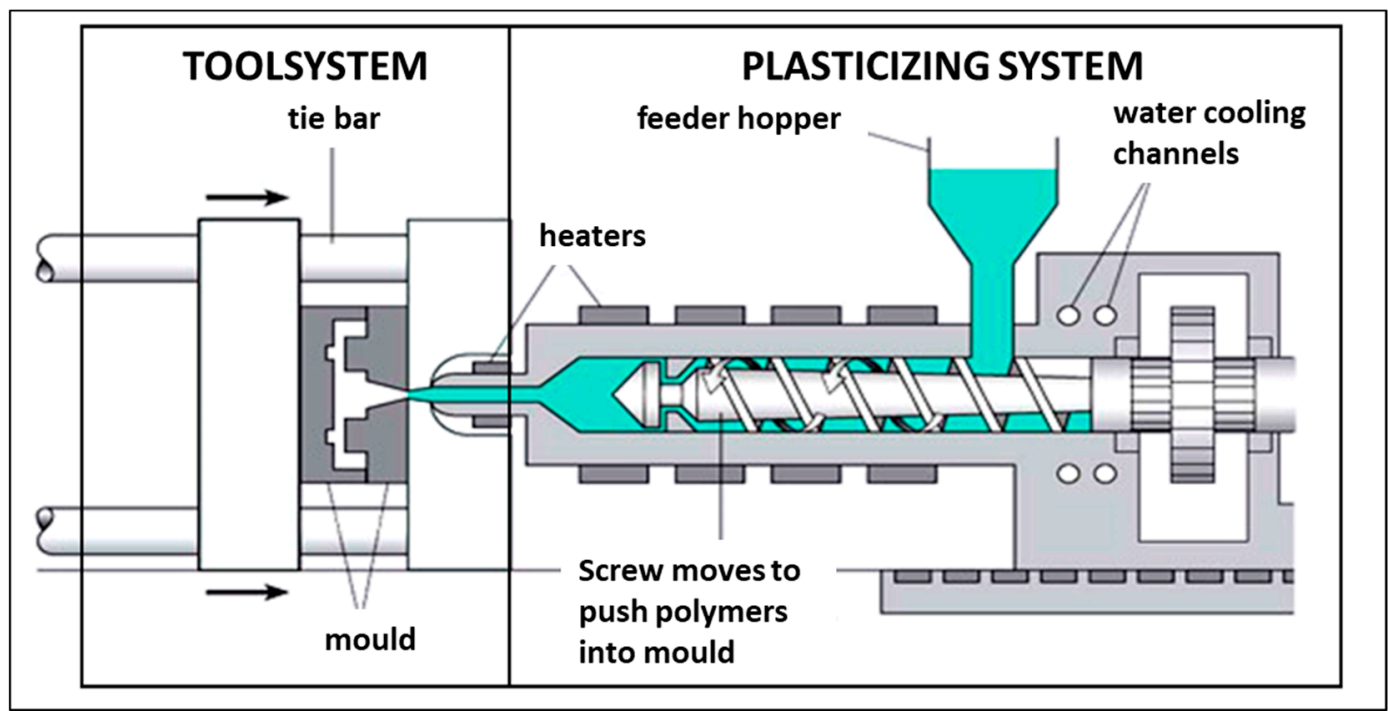

Figure 7. Injection moulding machine construction diagram. 


\section{Materials and Methods}

The plastic from which the airfield geocell was made has been subjected to material tests to determine physico-mechanical properties and to test its resistance to chemical agents used on airfield pavement during their year-round operation.

The finished technology of strengthening the natural airfield pavement with the finished product of an airfield geocell made from recycled plastic waste has been tested by a training ground.

\subsection{Static Flexural of Plastic Samples}

Static bending tests of plastic samples were carried out in accordance with PN-EN ISO 178:2019-06 Plastics. Determination of flexural properties [29]. The three-point bending tests were performed on eight rectangular samples (including three test samples) injected plastic measuring approximately $80 \mathrm{~mm} \times 10 \mathrm{~mm} \times 4 \mathrm{~mm}$. Figure 8 shows a view of the sample fixed in the strength machine before the test, and Figure 9 presents the view of the sample fixed in the strength testing machine after stopping the test [30].

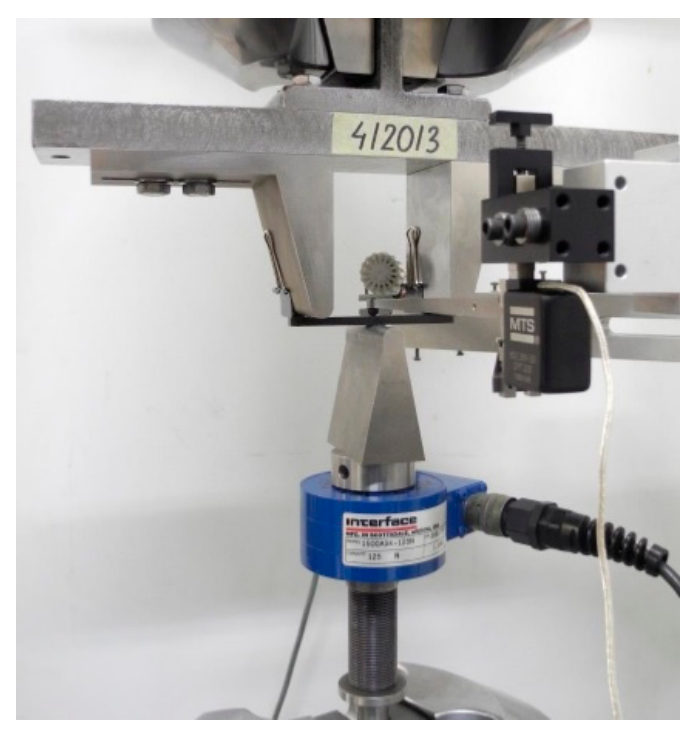

Figure 8. View of the sample fixed in the strength machine before the test.

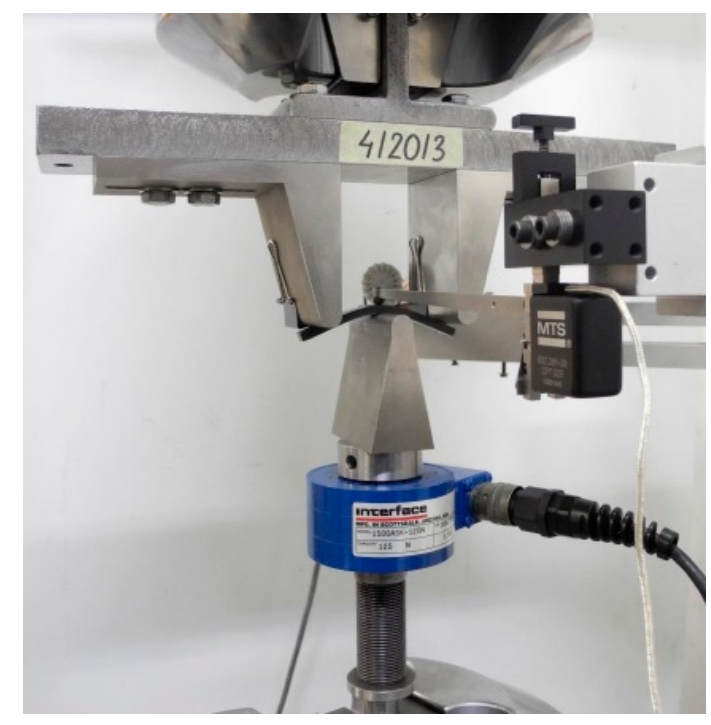

Figure 9. View of the sample fixed in the strength machine after stopping the test. 


\subsection{Static Tensile of Plastic Samples}

Static tensile testing of plastic samples has been carried out in accordance with PN-EN ISO 527-1:2020-01 Plastics. Determination of tensile properties. Part 1: General principles [31].

Static tensile tests were carried out on five samples, injection moulded plastic, with a total length, a measuring section width and thicknesses of approximately $170 \mathrm{~mm} \times$ $10 \mathrm{~mm} \times 4 \mathrm{~mm}$. An image of the sample fixed in the strength machine before the test is given in Figure 10, while the samples are placed in Figure 11 after the test has stopped [32].

The static tensile test was carried out at $\mathrm{v}=1 \mathrm{~mm} / \mathrm{min}$.

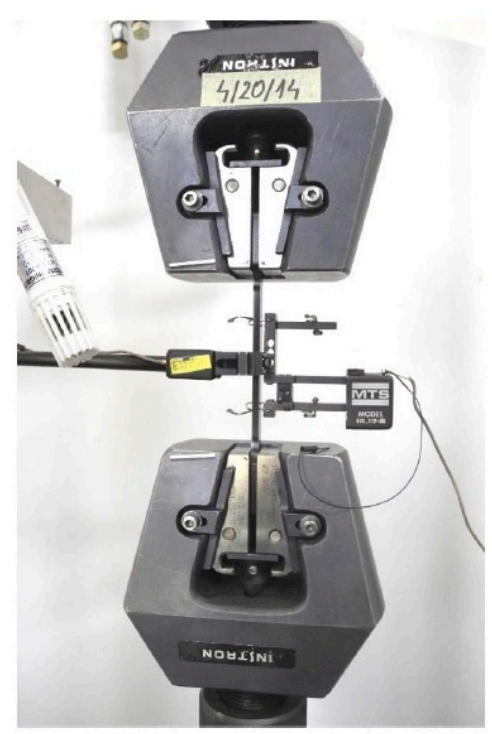

Figure 10. View of the sample fixed in the strength machine before the test.

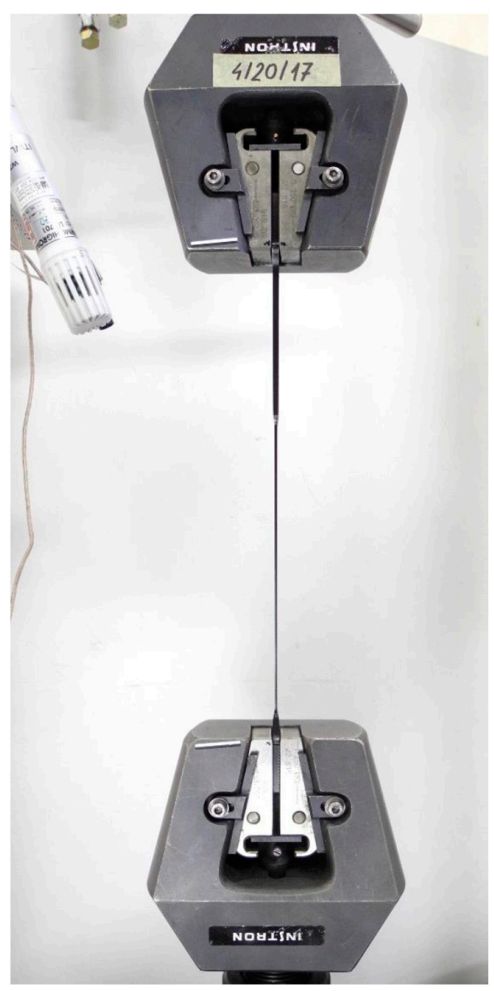

Figure 11. View of the sample fixed in the strength machine after stopping the test. 


\subsection{Compression Test of Airfield Geocell Made of Recycled Plastic Materials}

Compression studies of airfield geocell were carried out in accordance with PN-EN ISO 25619-2:2015-11 Geosynthetics. Determination of compression behaviour. Part 2: Determination of short-term compression behaviour [33].

Five airfield geocells (sample pre-test geocells-Figure 12) with dimensions of approximately $485 \mathrm{~mm} \times 485 \mathrm{~mm} \times 40 \mathrm{~mm}$ were tested and moulded plastic. Three geocells were compressed in the middle area, the other two were compressed in the corner area.

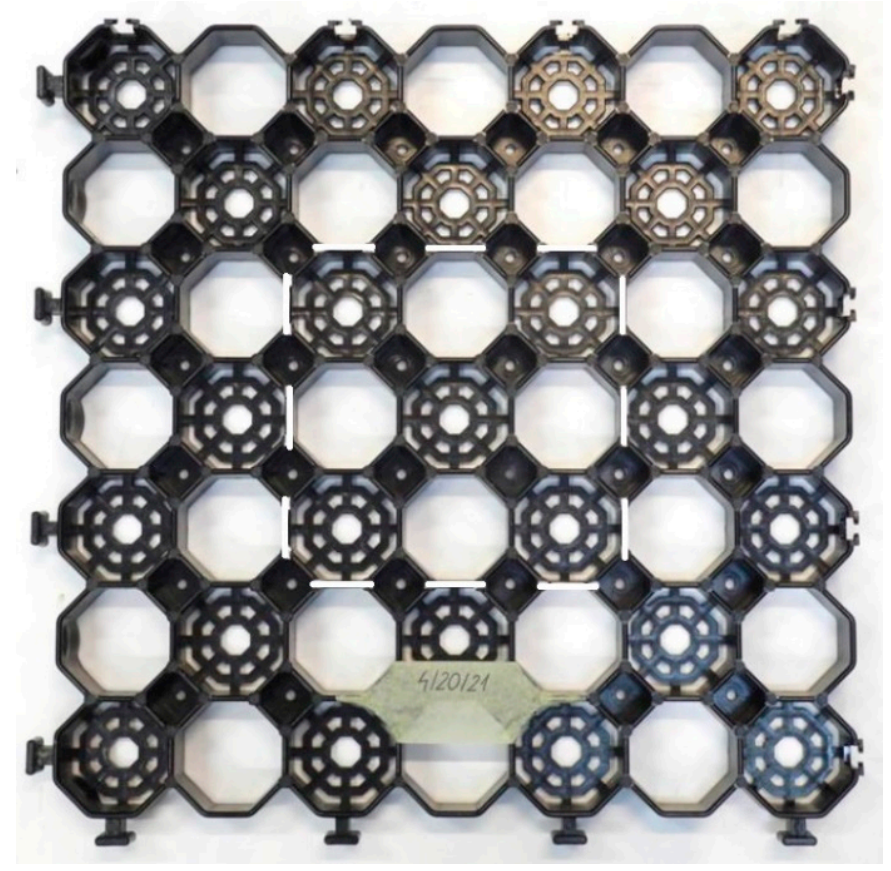

Figure 12. A picture of the geocell before the test; the position of the sample is marked with white lines; compression in the middle area.

Figure 13 shows a geocell put in the strength machine before the test, while Figure 14 shows a picture of the geocell after the test [34].

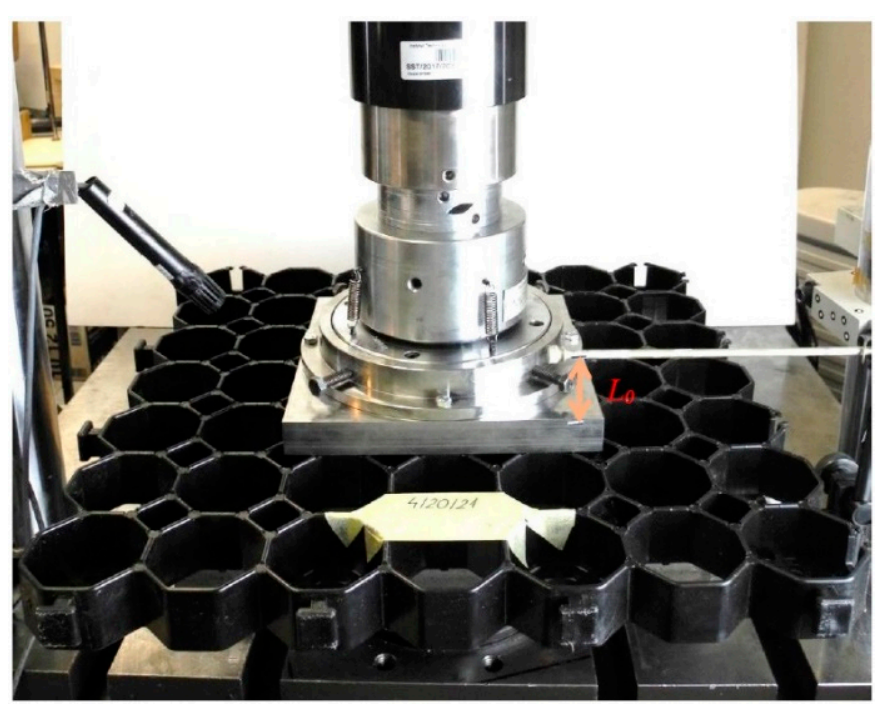

Figure 13. View of the geocell fixed in the strength machine. 


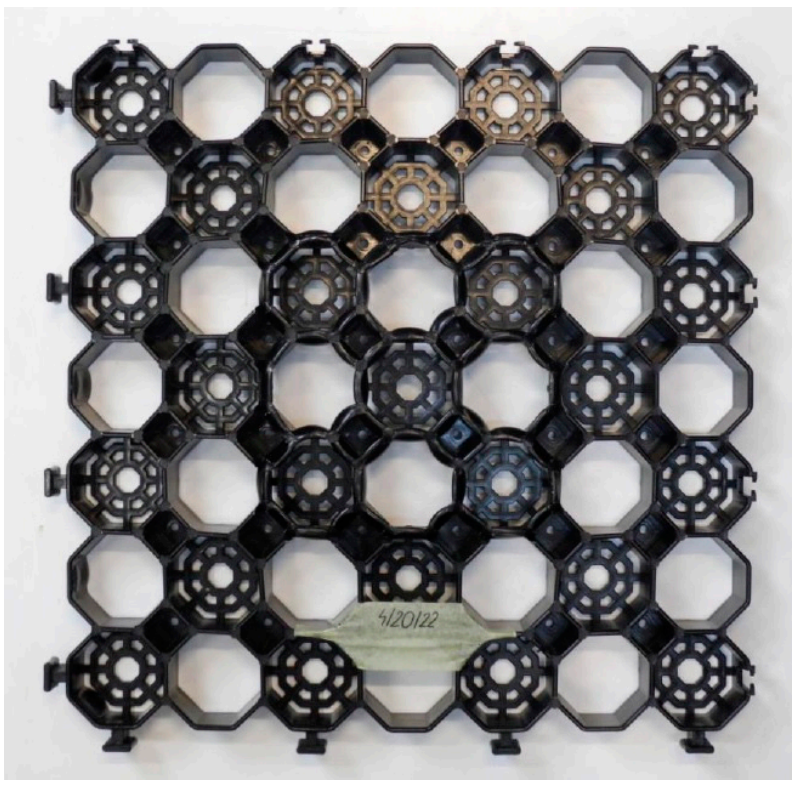

Figure 14. Image of the geocell after the test.

The preload (zero displacement of the moving compressive plate relative to the base plate) was approximately $5 \mathrm{kPa}$ corresponding to a force of $229 \mathrm{~N}$.

During the test, the following parameters were determined:

- Compressive strength during short-term compression, $\sigma_{\mathrm{mr}}[\mathrm{kPa}]$;

- Compressive strain determined from the displacement of the movable compressive plate relative to the base plate for the $\sigma_{\mathrm{mr}}, \varepsilon_{\mathrm{mr}}[\%]$;

- Compressive strain determined by a video-extensometer for the $\sigma_{\mathrm{mr}}, \varepsilon_{\mathrm{mr}, \mathrm{ve}}[\%]$.

\subsection{Determination of the Resistance of Plastic Samples to Consumables}

Samples made of plastic were influenced by consumables, i.e., water, airfield pavement de-icing agent based on potassium formate and Jet A1 aviation fuel. The samples were completely immersed in the individual media (Figures 15-17) and kept in there for a period of 14 days. The weight of the samples was measured on the individual days after they were dried with filter paper.

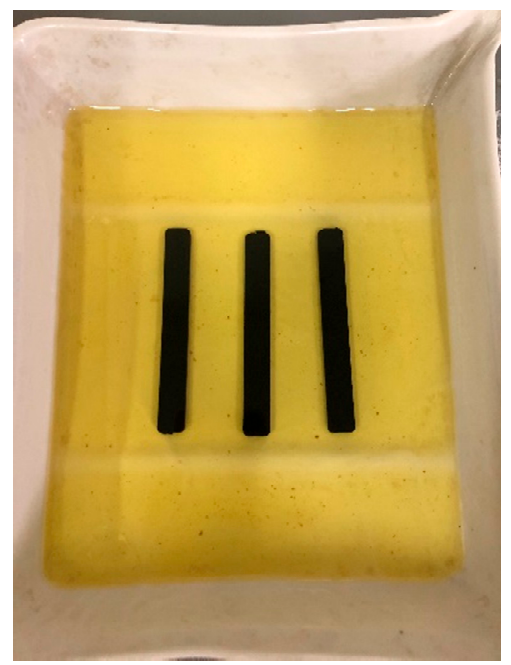

Figure 15. Plastic samples immersed in aviation fuel. 


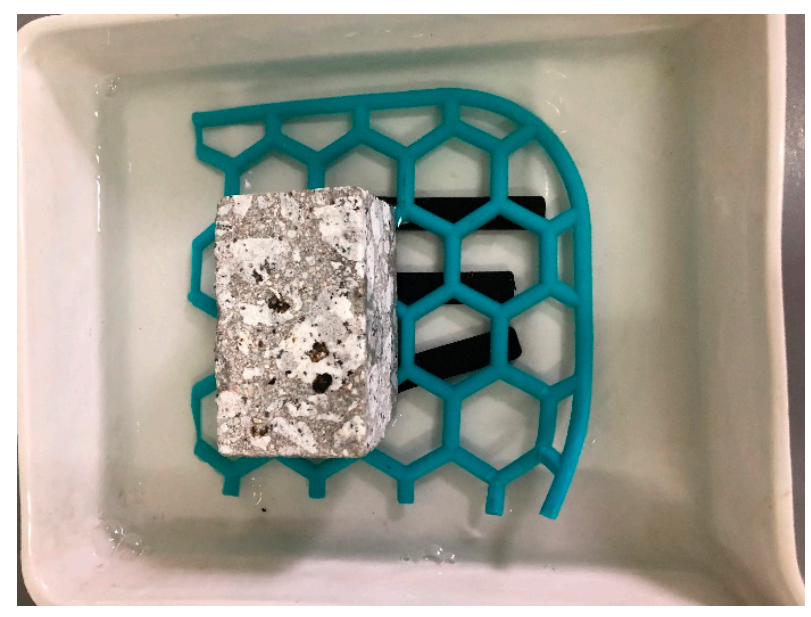

Figure 16. Plastic samples immersed in water.

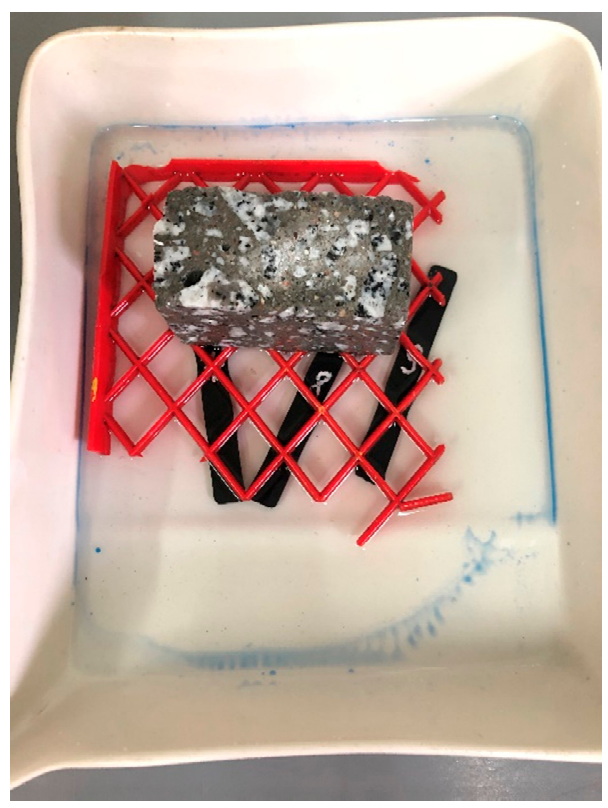

Figure 17. Plastic samples immersed in de-icing agent.

The effect of individual media on the test plastic was determined by calculating the absorbability of the individual samples based on a change of their weight. Absorbability $X[\%]$ was calculated according to the Equation (1):

$$
X=\frac{m_{1}-m}{m} \cdot 100
$$

where:

$m$-weight of the sample before immersion, $[\mathrm{g}]$;

$m_{1}$-mass of the sample after removal from the specified medium, [g].

\subsection{Method of Installation of Airfield Geocells on Natural Airfield Pavement}

The airfield geocell was installed by pushing it into the natural airfield pavements.

The airfield geocells are arranged on a designated area on experimental field. Vehicles with a weight of 6-10 tonnes are used to push the geocells. Rolling begins perpendicular to the row of geocells. Figures 18 and 19 shows the process of laying and pressing the airfield geocell into the natural pavement. 


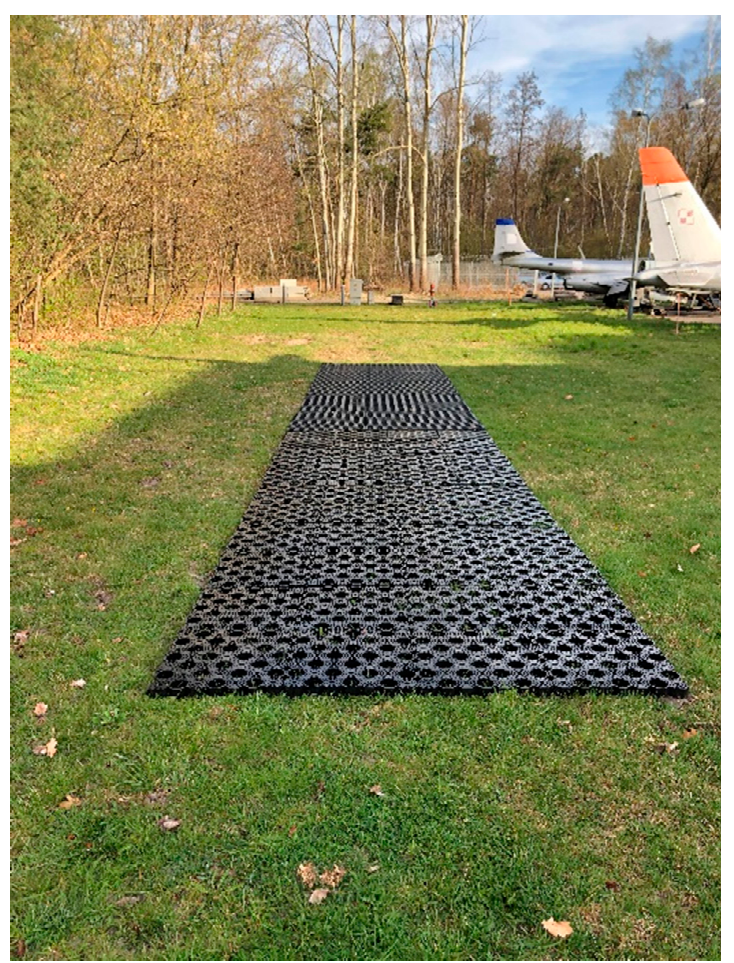

Figure 18. Airfield geocell ready to be pressed into the pavement.

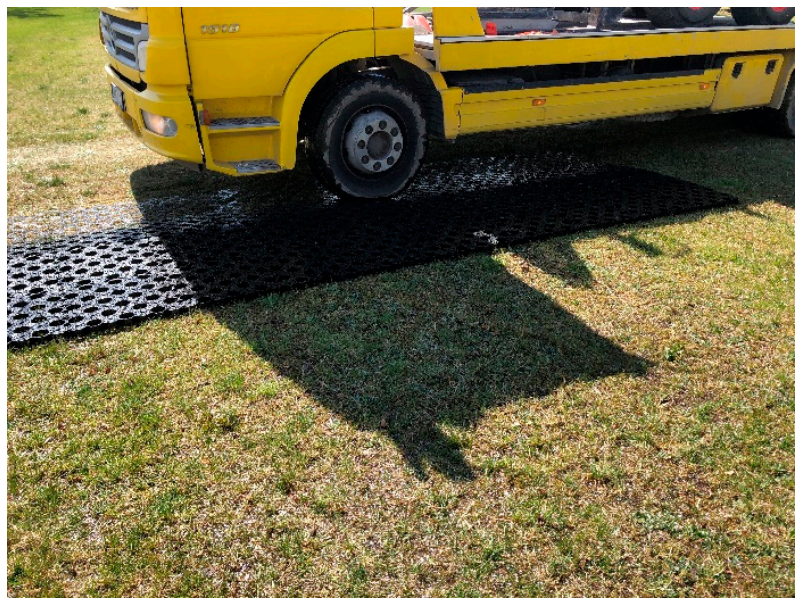

Figure 19. The process of pressing the airfield geocell into the natural airfield pavement.

2.6. Tests on the Load Capacity of the Natural Airfield Pavement Reinforced with an Airfield Geocell Made of Recycled Plastic Material

The HWD (Heavy Weight Deflectometer) airfield deflectometer was used to assess the load capacity of airfield pavement; Figure 20 shows the load capacity of the natural airfield pavement reinforced with airfield geocell. The test shall measure the elastic deflections of the test pavements formed under dynamic load on a discharge basis with a force of approximately $200 \mathrm{kN}$, on a pressure plate with a diameter of $0.45 \mathrm{~m}$, resting on the pavement and being carried out in accordance with defence standard NO-17-A500:2016 [35]. During the measurement, the deflections of the test pavement shall be recorded by geophones mounted on the measuring strip and centrally under the load plate of the device. The maximum distance of the measuring point from the centre of the loading plate shall be $2.5 \mathrm{~m}$ [36]. The results are recorded on your computer while illustrating deflection and stress waveforms and stresses over time on the monitor screen. 


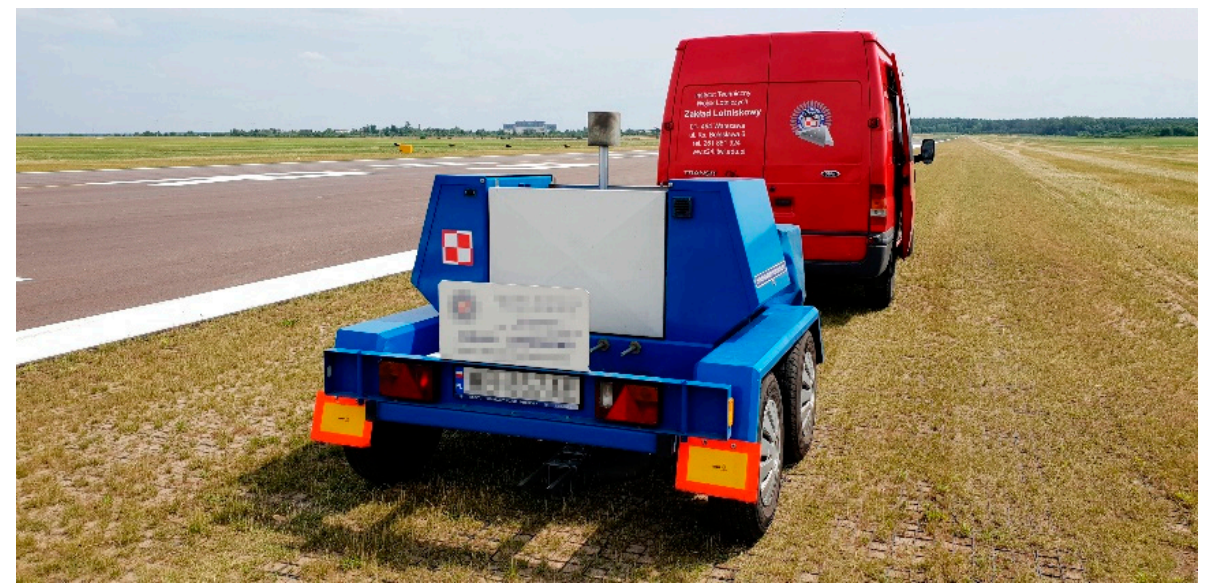

Figure 20. Measurement of load carrying capacity with HWD airport deflectometer.

The training ground tests for the load capacity of natural airfield not reinforced and the load capacity of the natural airfield pavement reinforced by the airfield geocell were carried out on four experimental plots.

On the basis of the deflection bowl and knowledge of the thickness of the layers of construction and the characteristics of the materials from which they are made, the elasticity modules of the individual layers are determined [36].

The result of surface measurements using the HWD airport deflectometer is the maximum elastic deflection values measured by geophones. This set of values is defined as the deflection bowl. The size of the deflections throughout the bowl is a relationship that can be described by the (2) [37]:

$$
U_{i}=f(h, E, v)
$$

where:

$U_{i}$ - the deflection value of the test surface at the point of $I$;

$f$-function relation of the components;

$h$-thickness of the particular pavement structural layers;

E-elasticity modulus of the particular structural layers of the pavement and subsoil;

$v$-Poisson's number of the pavement and subsoil's structural layers.

On the basis of the recorded values of the airport pavement's deflection, the elasticity modules of the materials of the particular layers are determined by iterative comparison of the values of the measured deflections and theoretical deflections, so that function $F$ has a minimum value. For this purpose, the following relationship is used (3) [37]:

$$
F=\sum_{j=1}^{k}\left(w_{j}-u_{j}\right)^{2}
$$

where:

F-approximation function of actual and theoretical values;

$w_{j}$-calculated pavement deflections at a distance of $\mathrm{r}$ from the centre of a loading plate;

$u_{j}$-measured pavement deflections at a distance of $\mathrm{r}$ from the centre of a loading plate;

$k$-number of geophones.

In the future, works are also planned to determine the usefulness of research on natural pavements with the use of GPR. It is aimed at a more detailed analysis of the anomalies in the ground subsoil on natural airfield pavements [38]. 


\section{Results}

\subsection{Static Flexural of Plastic Samples}

The results obtained for the determination of the elasticity module at flexural $E_{f}$ for a population of 8 samples are shown in Table 1 . The flexural elasticity module has been calculated according to the Equation (4):

$$
E_{f}=\frac{\sigma_{f 2}-\sigma_{f 1}}{\varepsilon_{f 2}-\varepsilon_{f 1}}
$$

where:

$\sigma_{f 1}$-is the flexural stress, measured at deflection $\mathrm{s}_{1},[\mathrm{MPa}]$;

$\sigma_{f 2}$-is the flexural stress, measured at deflection $\mathrm{s}_{2}$, [MPa].

Table 1. Results of determination of the elasticity module at flexural $E_{\mathrm{f}}$ for a population of 8 samples.

\begin{tabular}{|c|c|c|c|c|c|c|c|c|}
\hline $\begin{array}{l}\text { Sample } \\
\text { Number }\end{array}$ & $\begin{array}{c}\mathrm{E}_{\mathrm{f}}{ }^{1} \\
{[\mathrm{MPa}]}\end{array}$ & $\begin{array}{c}E_{\text {fśr }} \\
{[\mathrm{MPa}]}\end{array}$ & $\begin{array}{l}\mathrm{S}_{(\mathrm{Ef})}{ }^{2} \\
{[\mathrm{MPa}]}\end{array}$ & $\begin{array}{c}\mathrm{m}_{\mathrm{Ef}}{ }^{3} \\
{[\mathrm{MPa}]}\end{array}$ & $\begin{array}{c}\mathrm{E}_{\mathrm{fMNK}}{ }^{4} \\
{[\mathrm{MPa}]}\end{array}$ & $\begin{array}{c}\text { E}_{\text {fMNKśr }} \\
\text { [MPa] }\end{array}$ & $\begin{array}{c}\mathrm{S}_{\text {(EfMNK) }} \\
{[\mathrm{MPa}]}\end{array}$ & $\begin{array}{c}\mathrm{m}_{\text {EfMNK }}{ }^{6} \\
{[\mathrm{MPa}]}\end{array}$ \\
\hline 1 & 946 & \multirow{8}{*}{947} & \multirow{8}{*}{14.8} & \multirow{8}{*}{$935<\mathrm{m}_{\mathrm{Ef}}<959$} & 940 & \multirow{8}{*}{944} & \multirow{8}{*}{14.1} & \multirow{8}{*}{$932<\mathrm{m}_{\mathrm{EfMNK}}<956$} \\
\hline 2 & 935 & & & & 937 & & & \\
\hline 3 & 926 & & & & 925 & & & \\
\hline 4 & 938 & & & & 938 & & & \\
\hline 5 & 953 & & & & 948 & & & \\
\hline 6 & 973 & & & & 973 & & & \\
\hline 7 & 945 & & & & 940 & & & \\
\hline 8 & 959 & & & & 952 & & & \\
\hline
\end{tabular}

${ }^{1}$ modulus of elasticity in flexure, flexural modulus; ${ }^{2}$ standard deviation of the flexural elasticity module; ${ }^{3} 95 \%$ two-sided confidence interval of average values of the flexural elasticity module; ${ }^{4}$ flexural modulus determined from the slope of the regression line determined by the least squares method; ${ }^{5}$ standard deviation of the flexion elasticity module (regression), 6 95\% two-sided confidence interval of average values of the flexion elasticity module (regression).

Results of flexural stress determination at conventional bend $\sigma_{\mathrm{fC}}$ for a population of 8 samples are shown in Table 2.

Table 2. Results of flexural stress determination at conventional bend $\sigma_{\mathrm{fC}}$ for a population of 8 samples.

\begin{tabular}{|c|c|c|c|c|c|c|}
\hline Sample Number & $\begin{array}{c}\sigma_{\mathrm{fC}}{ }^{1} \\
{[\mathrm{MPa}]}\end{array}$ & $\begin{array}{c}\sigma_{\mathrm{fCśr}} \\
{[\mathrm{MPa}]}\end{array}$ & $\begin{array}{c}\mathrm{S}_{(\sigma \mathrm{fC})}{ }^{2} \\
{[\mathrm{MPa}]}\end{array}$ & $\begin{array}{c}\mathrm{m}_{\sigma \mathrm{fC}}{ }^{3} \\
{[\mathrm{MPa}]}\end{array}$ & $\begin{array}{c}\mathrm{S}_{\mathrm{C}}{ }^{4} \\
{[\mathrm{~mm}]}\end{array}$ & $\begin{array}{l}\varepsilon_{\mathrm{fC}}{ }^{5} \\
{[\%]}\end{array}$ \\
\hline 1 & 17.6 & \multirow{8}{*}{17.5} & \multirow{8}{*}{0.14} & \multirow{8}{*}{$17.4<\mathrm{m}_{\sigma \mathrm{fC}}<17.6$} & 5.938 & 3.44 \\
\hline 2 & 17.6 & & & & 5.925 & 3.43 \\
\hline 3 & 17.5 & & & & 5.952 & 3.46 \\
\hline 4 & 17.3 & & & & 5.958 & 3.46 \\
\hline 5 & 17.4 & & & & 5.918 & 3.42 \\
\hline 6 & 17.7 & & & & 5.928 & 3.43 \\
\hline 7 & 17.4 & & & & 5.924 & 3.42 \\
\hline 8 & 17.6 & & & & 5.934 & 3.44 \\
\hline
\end{tabular}

${ }^{1}$ flexural stress at the conventional deflection $\mathrm{S}_{\mathrm{C}} ;{ }^{2}$ standard deviation of flexural stress at conventional bending $\mathrm{S}_{\mathrm{C}} ;{ }^{3} 95 \%$ two-sided confidence interval of average values; ${ }^{4}$ conventional deflection; ${ }^{5}$ flexural deformation for conventional deflection $S_{C}$.

Graph of stress $\sigma_{\mathrm{f}}$ to strain $\varepsilon_{\mathrm{f}}$ (marked: points for determining the elasticity module at flexural, stress at conventional bend and maximum stress at deformation $\varepsilon_{\mathrm{f}}=5 \%$ ) is shown in the Figure 21.

During the static flexural test, the plastic samples were not broken before reaching the contractual value of the $\mathrm{S}_{\mathrm{C}}$ deflection arrow (conventional deflection). In this case, the size of the test material in terms of ability to carry bending loads is the stress at a specific deflection arrow $\sigma_{\mathrm{fC}}$. This is the highest normal (flexural) stress in the sample when deflection is reached $\mathrm{S}_{\mathrm{C}}$.

\subsection{Static Tensile of Plastic Samples}

The results obtained for the test samples are shown in tables: Table 3-determination of the tensile elasticity modulus $\mathrm{E}_{\mathrm{t}}$; Table 4-Poisson's number determination $\mu$; Table 5- 
maximum stress $\sigma_{\mathrm{m}}$ determination; Table 6-strain at maximum stress $\varepsilon_{\mathrm{tm}, \mathrm{ve}}$ determination; and Table 7 - stress at the end of the test $\sigma_{\mathrm{b}^{\prime}}$ determination.

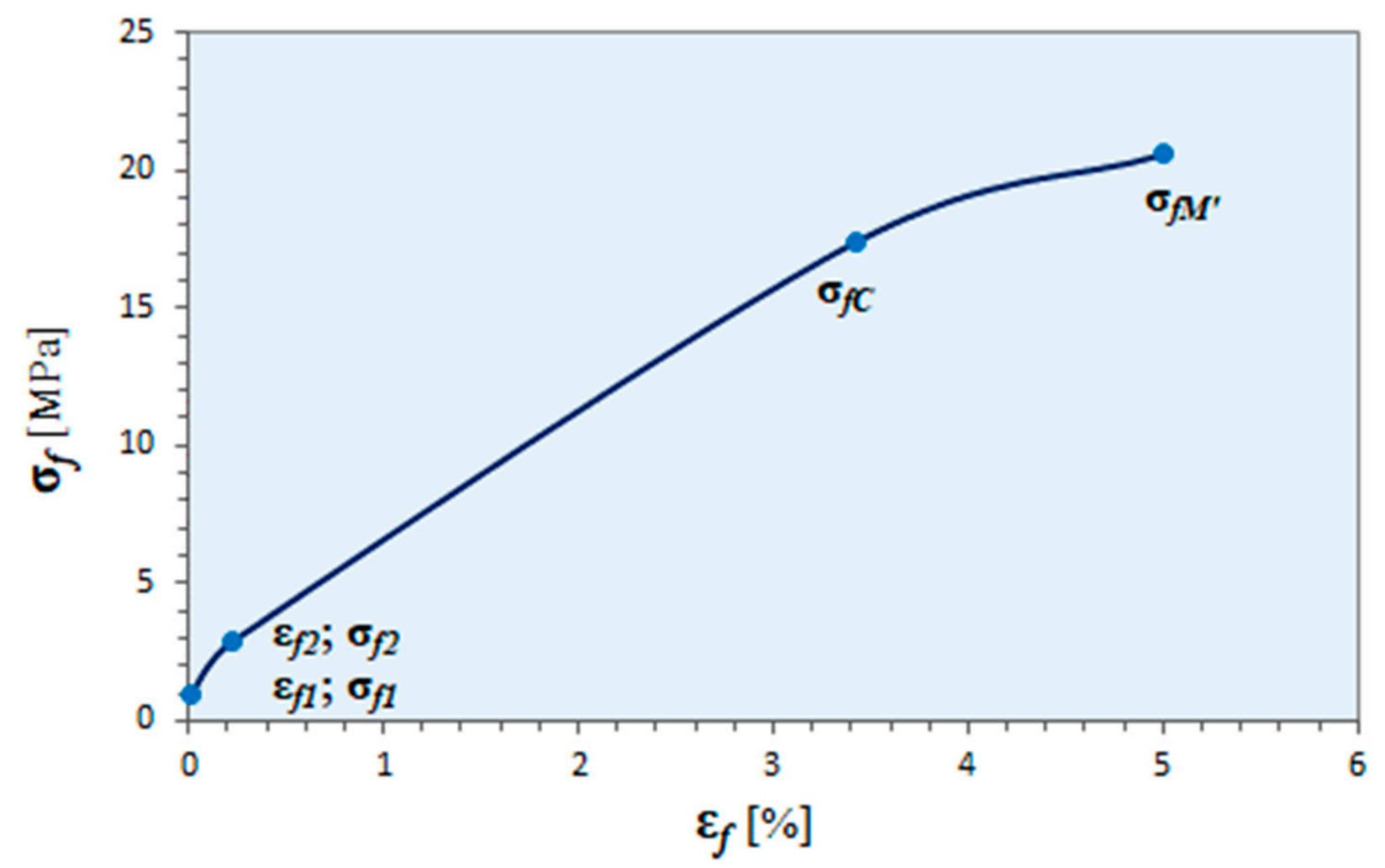

Figure 21. Graph of stress $\sigma_{\mathrm{f}}$ to strain $\varepsilon_{\mathrm{f}}$ (marked: points for determining the elasticity module at flexural, stress at conventional bend and maximum stress at deformation $\varepsilon_{\mathrm{f}}=5 \%$ ).

Table 3. Results of determination of the elasticity modulus under tension $E_{t}$ for a population of 5 samples.

\begin{tabular}{ccccc}
\hline Sample Number & $\begin{array}{c}\mathbf{E}_{\mathrm{t}}{ }^{\mathbf{1}} \\
{[\mathbf{M P a}]}\end{array}$ & $\begin{array}{c}\mathbf{E}_{\mathrm{t}, \mathrm{sr}} \\
{[\mathbf{M P a}]}\end{array}$ & $\begin{array}{c}\mathbf{S}_{(\mathrm{Et})}{ }^{2} \\
{[\mathbf{M P a}]}\end{array}$ & $\begin{array}{c}\mathbf{m}_{\mathrm{Et}}{ }^{3} \\
{[\mathbf{M P a}]}\end{array}$ \\
\hline 1 & 900 & & & \\
2 & 890 & 913 & 26.5 & $889<\mathrm{m}_{\mathrm{Et}}<939$ \\
3 & 897 & & & \\
4 & 955 & & &
\end{tabular}

${ }^{1}$ tensile modulus, modulus of elasticity under tension; ${ }^{2}$ standard deviation of the modulus of elasticity $\mathrm{E}_{\mathrm{t}} ;$ ${ }^{3} 95 \%$ two-sided confidence interval of average values.

Table 4. Poisson's number determination results $\mu$ for a population of 5 samples.

\begin{tabular}{|c|c|c|c|c|}
\hline Sample Number & $\begin{array}{c}\mu^{1} \\
{[-]}\end{array}$ & $\begin{array}{c}\mu_{\text {sr }} \\
{[-]}\end{array}$ & $\begin{array}{c}S_{\left(-\mu_{1}\right.}{ }^{2} \\
{[-]}\end{array}$ & $\begin{array}{c}\mathbf{m}_{\mu}{ }^{3} \\
{[-]}\end{array}$ \\
\hline 1 & 0.49 & & & \\
\hline 2 & 0.49 & & & \\
\hline 3 & 0.49 & 0.494 & 0.0 & $0.48<\mathrm{m}_{\mu}<0.50$ \\
\hline 4 & 0.50 & & & \\
\hline 5 & 0.50 & & & \\
\hline
\end{tabular}


Table 5. Results of the determination of the maximum stress $\sigma_{\mathrm{m}}$ for a population of 5 samples.

\begin{tabular}{ccccc}
\hline Sample Number & $\begin{array}{c}\boldsymbol{\sigma}_{\mathrm{m}} \mathbf{1}^{\mathbf{M P a}} \\
{[\mathbf{M P a}}\end{array}$ & $\begin{array}{c}\boldsymbol{\sigma}_{\mathrm{m}, \mathrm{sr}} \\
{[\mathbf{M P a}]}\end{array}$ & $\begin{array}{c}\mathbf{S}_{(\sigma \mathrm{m})} \mathbf{2}^{2} \\
{[\mathbf{M P a}]}\end{array}$ & $\begin{array}{c}\mathbf{m}_{\sigma \mathrm{m}}{ }^{3} \\
{[\mathbf{M P a}]}\end{array}$ \\
\hline 1 & 19.4 & & & \\
2 & 20.0 & & & \\
3 & 19.4 & 19.8 & 0.34 & \\
4 & 20.1 & & & \\
5 & 19.9 & & & \\
\hline
\end{tabular}

${ }^{1}$ stress at the first local maximum observed during a tensile test; ${ }^{2}$ standard deviation of strength $\sigma_{\mathrm{m}} ;{ }^{3} 95 \%$ twosided confidence interval of average values.

Table 6. Strain results at maximum stress $\varepsilon_{\mathrm{tm} \text {,ve }}$ for a population of 5 samples.

\begin{tabular}{|c|c|c|c|c|}
\hline Sample Number & $\begin{array}{c}\mathcal{E}_{\mathrm{tm}, \mathrm{ve}}{ }^{1} \\
{[\%]}\end{array}$ & $\begin{array}{c}\mathcal{E}_{\mathrm{tm}, \mathrm{ve}, \mathrm{s} r} \\
{[\%]}\end{array}$ & $\begin{array}{c}\mathrm{S}_{\left(\varepsilon_{\mathrm{tm}, \mathrm{ve})}{ }^{2}\right.} \\
{[\%]}\end{array}$ & $\mathbf{m}_{\mathfrak{\varepsilon} t \mathrm{tm}, \mathrm{ve}}{ }^{3}$ \\
\hline 1 & 10.2 & & & \\
\hline 2 & 9.5 & & & \\
\hline 3 & 10.5 & 10.1 & 0.40 & $9.7<\mathrm{m}_{\varepsilon \mathrm{tm} . \mathrm{ve}}<10.5$ \\
\hline 4 & 9.8 & & & \\
\hline 5 & 10.3 & & & \\
\hline
\end{tabular}

${ }^{1}$ nominal strain in the longitudinal direction at maximum stress $\sigma_{\mathrm{m}}{ }^{2}$ standard deviation of nominal strain in the longitudinal direction at maximum stress $\varepsilon_{\mathrm{tm}, \mathrm{ve}} ;{ }^{3} 95 \%$ two-sided confidence interval of average values.

Table 7. Stress determination results at the end of test $\sigma_{\mathrm{b}^{\prime}}$ for a population of 5 samples.

\begin{tabular}{|c|c|c|c|c|c|}
\hline Sample Number & $\begin{array}{c}\sigma_{\mathbf{b}^{\prime}}{ }^{1} \\
{[\mathrm{MPa}]}\end{array}$ & $\begin{array}{c}\sigma_{\mathbf{b}^{\prime}, \mathbf{s} \mathbf{r}} \\
{[\mathbf{M P a}]}\end{array}$ & $\begin{array}{c}\mathrm{S}_{\left(\sigma_{\left.\mathrm{b}^{\prime}\right)}\right.}{ }^{2} \\
{[\mathrm{MPa}]}\end{array}$ & $\begin{array}{l}\mathbf{m}_{\sigma \mathbf{b}^{\prime}}{ }^{3} \\
{[\mathrm{MPa}]}\end{array}$ & $\begin{array}{c}\mathcal{E}_{\mathrm{tb}, \mathrm{ve}^{\prime}} \\
{[\%]}\end{array}$ \\
\hline 1 & 14.1 & & & & \\
\hline 2 & 14.4 & & & & \\
\hline 3 & 13.7 & 14.2 & 0.29 & $13.9<\mathrm{m}_{\sigma \mathrm{b}^{\prime}}<14.5$ & 160 \\
\hline 4 & 14.4 & & & & \\
\hline 5 & 14.2 & & & & \\
\hline
\end{tabular}

1 stress at break; ${ }^{2}$ standard deviation of stress at the end of the test $\sigma_{\mathrm{b}^{\prime}} ;{ }^{3} 95 \%$ two-sided confidence interval of average values; ${ }^{4}$ nominal strain in the longitudinal direction at $\sigma_{\mathrm{b}^{\prime}}$ stress; determined if the sample has not broken.

A graph of stress $\sigma$ on the strain $\varepsilon_{1}$ for one of the samples is shown in Figure 22, while the stress $\sigma$ relation to the strain $\varepsilon_{\mathrm{t}, \mathrm{ve}}$ graph is shown in Figure 23.

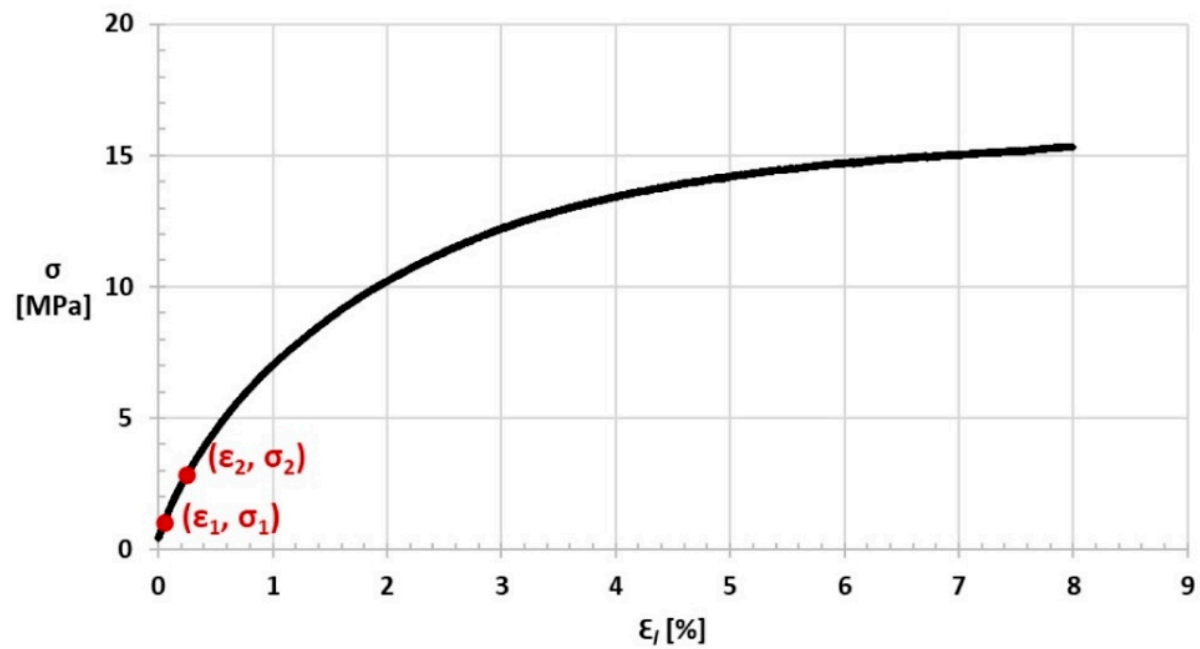

Figure 22. Stress $\sigma$ relation to $\varepsilon_{1}$ strain graph (points to determine the tensile modulus $E_{t}$ are selected). 


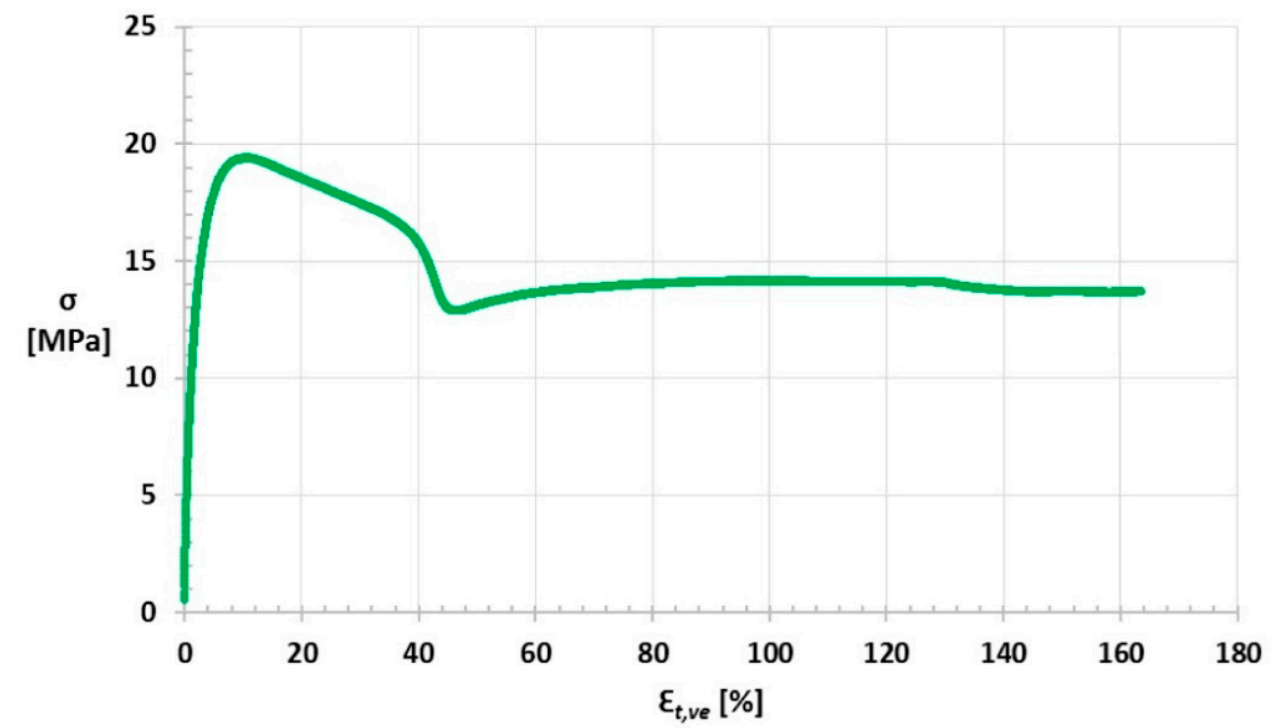

Figure 23. Stress $\sigma$ relation to strain $\varepsilon_{\mathrm{t}, \text { ve }}$ graph.

The test samples were not broken, a sample rupture or elongation of the sample measured using an elongated extensometer equal to that of the $4 \mathrm{~mm}$.

\subsection{Compression Test of Airfield Geocell Made of Recycled Plastic Materials}

The results obtained for the test samples are presented in tables: Table 8-results of determination of compressive strength $\sigma_{\mathrm{mr}}$; Table 9-compressive strain results $\varepsilon_{\mathrm{mr}}$ determined from the displacement of the moving compressive plate relative to the base plate; and Table 10—compressive strain results $\varepsilon_{\text {mr,ve }}$ determined by video-extensometer.

Table 8. Results of determination of compressive strength $\sigma_{\mathrm{mr}}$.

\begin{tabular}{cccc}
\hline Sample Number & $\begin{array}{c}\boldsymbol{\sigma}_{\mathbf{m r}} \\
{[\mathbf{k P a}]}\end{array}$ & $\begin{array}{c}\boldsymbol{\sigma}_{\mathbf{m r}, \mathbf{s} \mathbf{r}} \\
{[\mathbf{k P a}]}\end{array}$ & $\begin{array}{c}\mathbf{S}_{(\mathbf{\sigma m r})} \\
{[\mathbf{k P a}]}\end{array}$ \\
\hline 1 & 4836 & & \\
2 & 4817 & 4811 & \\
3 & 4781 & & \\
\hline $1-1$ & 4110 & & \\
$1-2$ & 3759 & & \\
$1-3$ & 4082 & & \\
$1-4$ & 4287 & & \\
\hline
\end{tabular}

Table 9. Results of determination of strain at compression $\varepsilon_{\mathrm{mr}}$.

\begin{tabular}{cccc}
\hline Sample Number & $\begin{array}{c}\varepsilon_{\mathrm{mr}} \\
{[\%]}\end{array}$ & $\begin{array}{c}\varepsilon_{\mathrm{mr}, \mathbf{s} r} \\
{[\%]}\end{array}$ & $\begin{array}{c}\mathbf{S}_{(\varepsilon \mathrm{mr})} \\
{[\%]}\end{array}$ \\
\hline 1 & 20 & & 0.6 \\
2 & 21 & 20 & \\
3 & 20 & & \\
\hline $1-1$ & 19 & & \\
$1-2$ & 18 & & \\
$1-3$ & 18 & & \\
\hline
\end{tabular}


Table 10. Results of determination of strain at compression $\varepsilon_{\mathrm{mr}, \mathrm{e}}$.

\begin{tabular}{cccc}
\hline Sample Number & $\begin{array}{c}\varepsilon_{\text {mr,ve }} \\
{[\%]}\end{array}$ & $\begin{array}{c}\varepsilon_{\text {mr,ve,śr }} \\
{[\%]}\end{array}$ & $\begin{array}{c}\mathbf{S}_{(\varepsilon \mathbf{m r}, v e)} \\
{[\%]}\end{array}$ \\
\hline 1 & 14 & & 0.0 \\
2 & 14 & 14 & \\
3 & 14 & & \\
\hline $1-1$ & 16 & & \\
$1-2$ & 16 & & \\
$1-3$ & 15 & & \\
\hline
\end{tabular}

A graph of the stress $\sigma_{\mathrm{mr}}$ relation to the deformation of $\varepsilon_{\mathrm{mr}}$ and $\varepsilon_{\mathrm{mr}, \mathrm{ve}}$ for one of the samples is shown in Figure 24.

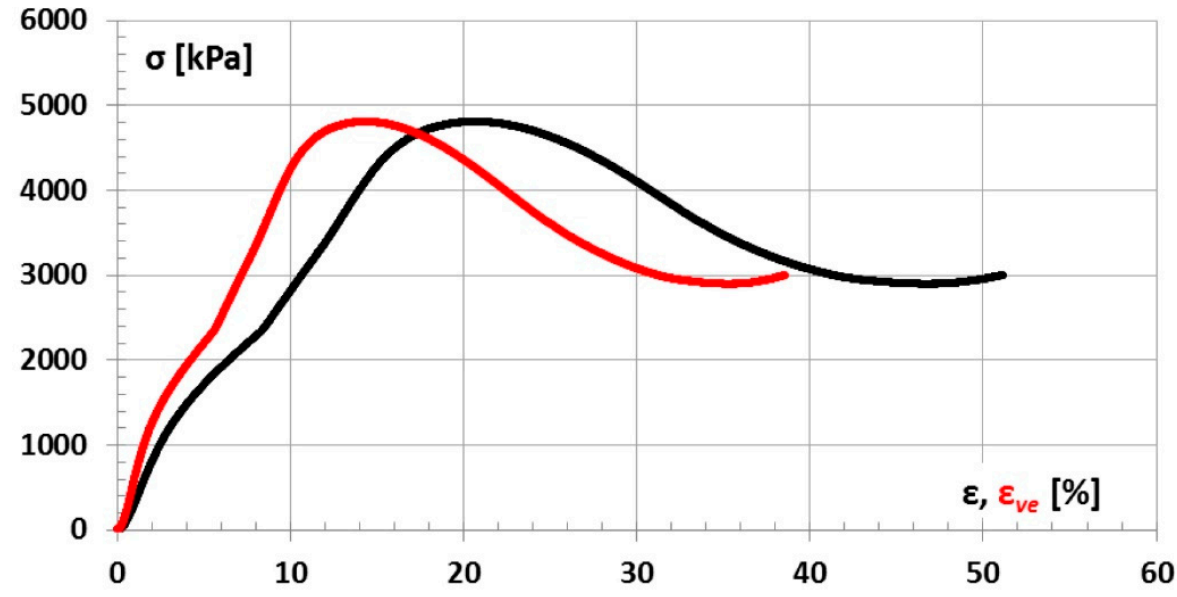

Figure 24. Stress $\sigma$ relation to strain $\varepsilon$ and $\varepsilon_{\mathrm{ve}}$ graph.

\subsection{Determination of the Resistance of Plastic Samples to Consumables}

The results of the tests carried out are shown in Table 11, in which $\mathrm{s}$ is the standard deviation and $\mathrm{v}$ is the coefficient of variation in percentage.

Table 11. Summary of plastic resistance test results after 14 days of soaking in consumables.

\begin{tabular}{|c|c|c|c|c|c|}
\hline Medium & $\begin{array}{l}\text { Sample } \\
\text { Number }\end{array}$ & $\begin{array}{l}\text { Weight before } \\
\text { Soaking m [g] }\end{array}$ & $\begin{array}{c}\text { Weight after } \\
\text { Soaking } \mathrm{m}_{1}[\mathrm{~g}]\end{array}$ & $\begin{array}{c}\text { Weight } \\
\text { Change [\%] }\end{array}$ & $\begin{array}{c}\text { Absorption } \\
\text { Average Value [\% }\end{array}$ \\
\hline \multirow{3}{*}{ Water } & 1 & 2.935 & 2.938 & 0.003 & 0.14 \\
\hline & 2 & 2.913 & 2.918 & 0.005 & $\mathrm{~s}=0.035$ \\
\hline & 3 & 2.919 & 2.923 & 0.004 & $\mathrm{v}=25.3$ \\
\hline \multirow{3}{*}{$\begin{array}{l}\text { De-icing } \\
\text { agent }\end{array}$} & 4 & 2.94 & 2.944 & 0.004 & 0.11 \\
\hline & 5 & 2.933 & 2.935 & 0.002 & $\mathrm{~s}=0.039$ \\
\hline & 6 & 2.933 & 2.937 & 0.004 & $\mathrm{v}=34.6$ \\
\hline \multirow{3}{*}{$\begin{array}{l}\text { Aviation } \\
\text { fuel }\end{array}$} & 7 & 2.935 & 3.029 & 0.094 & 3.17 \\
\hline & 8 & 2.939 & 3.031 & 0.092 & $\mathrm{~s}=0.038$ \\
\hline & 9 & 2.92 & 3.013 & 0.093 & $\mathrm{v}=1.2$ \\
\hline
\end{tabular}

The tests concluded that the test plastic is resistant to water, de-icing and aviation fuel-no signs of mass degradation were observed in the samples tested. The plastic in question shows the highest water absorption after immersion in aviation fuel, i.e., about $3 \%$. 


\subsection{Tests on the Load Capacity of the Natural Airfield Pavement Reinforced with an Airfield Geocell Made of Recycled Plastic Material}

Tests on the load capacity of the subsoil and the structural system of the subsoil and the airfield geocell pressed into it made of recycled plastic material were carried out on four experimental field.

The load bearing capacity obtained from the HWD tests are shown in Figure 25.

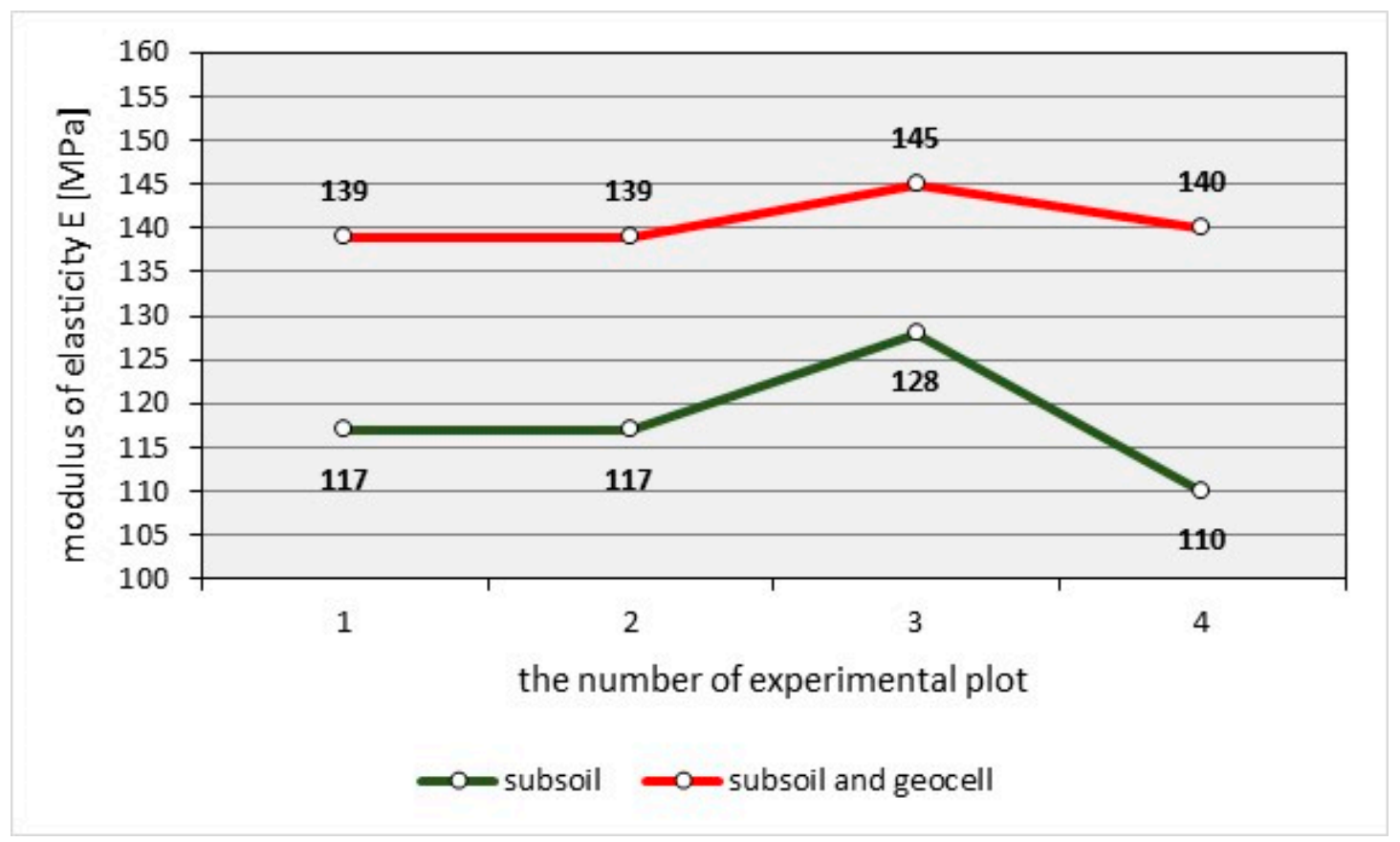

Figure 25. Comparison of the values of the modulus of elasticity obtained on the subsoil and on the structure of the natural pavement with airfield geocell.

The graph shows the results of the modulus of elasticity for unreinforced pavement, which range from $\mathrm{E}=110 \mathrm{MPa}$ to $\mathrm{E}=128 \mathrm{MPa}$ [39]. Reinforced natural pavement with airfield geocell have a modulus of elasticity between $\mathrm{E}=139 \mathrm{MPa}$ to $\mathrm{E}=145 \mathrm{MPa}$ [39].

The load-bearing capacity of natural airfield pavement reinforced with a pushing plastic airfield geocell has improved by an average of about $20 \%$.

\section{Discussion}

On the basis of laboratory and field tests carried out during the study, it is concluded that airfield geocell made of recycled plastic material improves the load-bearing capacity parameter of natural airfield pavement and can be used as a reinforcement.

Strength laboratory tests have shown that the recycled plastic material from which the airfield geocell is made has good mechanical properties (tensile, flexural, compression) and is resistant to consumables used at airports, i.e., aviation fuel, de-icing agents and water. The greatest water absorbability of the material is after immersion in aviation fuel, i.e., about $3 \%$.

During the strength tests of the plastic, the tensile elasticity modulus was $913 \mathrm{MPa}$ and the maximum stress was $19.8 \mathrm{MPa}$. The flexion modulus was $947 \mathrm{MPa}$, while the maximum flexural stress at $5 \%$ deformation reached $20.6 \mathrm{MPa}$. The compressive strength at the central point of the airfield geocell reached $4811 \mathrm{kPa}$.

This airfield geocell was made by injection method of polyethylene chemical called 1-butene, polymer with ethene. Typical plastic properties are shown in Table 12. The manufacturer of the plastic in question declares that it is resistant to acids, lyes and alcohols. 
Table 12. Typical properties of the plastic from which the airfield geocell is made of.

\begin{tabular}{|c|c|c|c|}
\hline Typical Properties & Nominal Value & Unit & Test Method \\
\hline Flow rate indicator (MFR) & & & \multirow{3}{*}{ ISO $1133-1$ [40] } \\
\hline $190^{\circ} \mathrm{C} / 2.16 \mathrm{~kg}$ & 4.0 & $\mathrm{~g} / 10 \mathrm{~min}$ & \\
\hline $190^{\circ} \mathrm{C} / 5.0 \mathrm{~kg}$ & & $\mathrm{~g} / 10 \mathrm{~min}$ & \\
\hline Density & 0.955 & $\mathrm{~g} / \mathrm{cm}^{3}$ & ISO 1183-1 [41] \\
\hline Tensile flexibility modulus & 1200 & $\mathrm{MPa}$ & ISO $527-1,-2[31,42]$ \\
\hline Stress at the yield strength limit & 27 & $\mathrm{MPa}$ & ISO $527-1,-2$ \\
\hline Elongation at the yield strength & 8 & $\%$ & ISO $527-1,-2$ \\
\hline FNCT $\left(3.5 \mathrm{MPa} 2 \%\right.$ Arkopal N100 $\left.80^{\circ} \mathrm{C}\right)$ & 4.5 & $\mathrm{~h}$ & ISO $16770[43]$ \\
\hline \multicolumn{4}{|l|}{ Toughness with notch according to } \\
\hline Charpy'ego & 4.0 & $\mathrm{~kJ} / \mathrm{m}^{2}$ & \multirow{3}{*}{ ISO 179 [44] } \\
\hline $23^{\circ} \mathrm{C}$, Type 1 , karb A & 4.5 & $\mathrm{~kJ} / \mathrm{m}^{2}$ & \\
\hline$-30^{\circ} \mathrm{C}$, Type 1, karb A & & & \\
\hline Shore Hardness (Shore D) & 60 & - & ISO 868 [45] \\
\hline Ball hardness (H 132/30) & 52 & $\mathrm{MPa}$ & ISO 2039-1 [46] \\
\hline Vicata softening temperature $(\mathrm{B} / 50 \mathrm{~N})$ & 73 & ${ }^{\circ} \mathrm{C}$ & ISO 306 [47] \\
\hline
\end{tabular}

The load-bearing capacity of natural airfield pavement reinforced with a pushing plastic airfield geocell has improved by an average of about $20 \%$.

In conclusion, recycled plastic material is useful for the production of airfield geocell. Due to its strength characteristics, the airfield geocell shall not be damaged or destroyed after application of the load [48]. Plastic is highly resistant to consumables such as water, aviation fuel and de-icing agents, which is very important as they are used on airfield pavements.

The main advantage of using plastic airfield geocells is the ability to quickly restore the operational capacity of the airport. The use of recycled materials is a more advantageous solution in financial terms compared to the construction of, e.g., rigid concrete pavement. Consequently, although it is a plastic it has a lower negative impact on the environment in comparison to the cement concrete production.

\section{Conclusions}

Research on the use of an airfield geocell to strengthen natural airfield pavements was started in 2018 at one of the aeroclub airports in Poland. Research on the load-bearing capacity of natural airfield pavements reinforced with an airfield geocell carried out in 2018-2020 confirmed the effectiveness of the proposed solution. The airfield geocell did not degrade after 3 years of use.

The direction of further work will include the continuation of field verification tests on real airport facilities and the improvement of load capacity and safety for military and civil aircraft with a weight exceeding $5700 \mathrm{~kg}$, so that the pavement reinforced with the airfield geocell meets the load capacity requirements.

Author Contributions: Conceptualization, M.W.; methodology, M.W. and A.K.; formal analysis, writing - original draft preparation, A.K.; resources, data curation, P.I.; formal analysis, writingreview and editing, M.W. and P.W. All authors have read and agreed to the published version of the manuscript.

Funding: This research received no external funding.

Institutional Review Board Statement: Not applicable.

Informed Consent Statement: Not applicable.

Data Availability Statement: The data presented in this study are available on request from the corresponding author.

Conflicts of Interest: The authors declare no conflict of interest. 


\section{References}

1. Wesołowski, M.; Poświata, A. Airfield pavements as an element of critical infrastructure in the airport safety management process. Commun. Overv. 2017, 11, 22-26. [CrossRef]

2. Nita, P. Construction and Maintenance of Airport Pavements, 2nd ed.; Publications of Communication and Communications: Warsaw, Poland, 2008; p. 19.

3. International Civil Aviation Organization. Annex 14 to the Convention on International Civil Aviation, 7th ed.; International Civil Aviation Organization: Montreal, QC, Canada, 2016; Volume 1.

4. Standard PN-S-02202: 1998 Roads_Earthworks—Specifications and Testing; PKN: Warsaw, Poland, 1998.

5. Standard NO-17-A503:2017 Airfield Pavements. Natural Airfield Pavements. Load Bearing Capacity Tests; MON: Warsaw, Poland, 2017.

6. Available online: http:/ / www.planecrashinfo.com (accessed on 21 May 2021).

7. Wesołowski, M.; Kowalska, D.; Kowalewska, A. Geocell reinforcement in natural airfield pavement structure in the aspect of the safety of conducted flight operations. In Proceedings of the 29th European Safety and Reliability Conference, Hannover, Germany, 22-26 September 2019; Beer, M., Zio, E., Eds.; Research Publishing: Singapore, 2019. [CrossRef]

8. Standard PN-EN ISO 10318:2007 Geosynthetics-Terms and Definitions; PKN: Warsaw, Poland, 2007.

9. Zhao, M.; Zhang, L.; Zou, X.; Zhao, H. Research progress in two-direction composite foundation formed by geocell reinforced mattress and gravel piles. Chin. J. Highw. Transp. 2009, 22, 1-10.

10. ASTM D 4439-00 Standard Terminology for Geosynthetics; ASTM: West Conshohocken, PA, USA, 2020.

11. Groenler, J.; Monlux, S.; Vachowski, B. Geosynthetics for Trails in Wet Areas, Missoula; United States Department of Agriculture: Washington, DC, USA, 2008.

12. Koerner, R.M. Design with Geosynthetics, 6th ed.; Xlibris: Bloomington, IA, USA, 2012; Volume 1.

13. Presto GeoSystem. Available online: https://www.prestogeo.com (accessed on 21 May 2021).

14. Guo, J.; Han, J.; Schrock, S.D.; Parsons, R.L. Field evaluation of vegetation growth in geocell-reinforced unpaved shoulders. Geotext. Geomembr. 2015, 43, 403-411. [CrossRef]

15. Han, J.; Thakur, J.K.; Parsons, R.L.; Pokharel, S.K.; Leshchinsky, D.; Yang, X. A summary of research on geocell-reinforced base courses. In Proceedings of the 2013 Design and Practice of Geosynthetic-Reinfoced Soil Structures, Bologna, Italy, 14-16 October 2013. [CrossRef]

16. Kief, O.; Schary, Y.; Pokharel, S. High-modulus geocells for sustainable highway infrastructure. Indian Geoetchnical J. 2015, 45, 289-400. [CrossRef]

17. Novus HM. Available online: https:/ / www.novus-hm.com (accessed on 25 May 2021).

18. PERFO. Available online: http:/ / www.perfo.co.uk (accessed on 25 May 2021).

19. Aviation Overview. Available online: www.plar.pl (accessed on 25 May 2021).

20. Osiecka, E. Building Materials, Plastics, 1st ed.; University of Warsaw University of Technology: Warsaw, Poland, 2005.

21. Wagner, A.H.; Yu, J.S.; Kalyon, D.M. Injection molding of engineering plastics. Adv. Polym. Technol. 1989, 9, 17-32. [CrossRef]

22. Wroclaw University of Technology. Available online: www.tworzywa.pwr.wroc.pl (accessed on 27 May 2021).

23. Gruin, I.; Ryszkowska, J.; Markiewicz, B. Polymeric Materials, 1st ed.; University of Warsaw University of Technology: Warsaw, Poland, 1996.

24. Peacock, A.J. Handbook of Polyethylene. Structures, Properties and Applications; CRC Press: Boca Raton, FL, USA, 2000.

25. Malinowski, R.; Łubkowski, D. Effect of selected injection process parameters on polypropylene physicochemical properties. Chemist 2009, 62, 425-430.

26. Kashyap, S.; Datta, D. Process parameter optimization of plastic injection molding: A review. Int. J. Plast. Technol. 2015, 19, 1-18. [CrossRef]

27. Iwko, J. Polymer plastic injection technology. Guide of the plastics processor. Poradnik Przetwórcy Tworzyw Sztucznych 2010, 40-42.

28. Szymański, S. Plastics Processing; Gdansk University of Technology: Gdansk, Poland, 2012.

29. Standard PN-EN ISO 178:2019-06 Plastics-Determination of Flexural Properties; PKN: Warsaw, Poland, 2019.

30. Lisiecki, J.; Baran, M. Report on the Static Bending Test of Plastic Samples; Air Force Institute of Technology: Warsaw, Poland, 2020.

31. Standard PN-EN ISO 527-1:2020-01 Plastics-Determination of Tensile Properties-Part 1: General Principles; PKN: Warsaw, Poland, 2020.

32. Baran, M.; Lisiecki, J.; Nowakowski, D. Report on the Static Tensile Testing of Plastic Samples; Air Force Institute of Technology: Warsaw, Poland, 2020.

33. Standard PN-EN ISO 25619-2:2015-11 Geosynthetics-Determination of Compression Behaviour-Part. 2: Determination of Short-Term Compression Behaviour; PKN: Warsaw, Poland, 2015.

34. Lisiecki, J.; Baran, M. Raport z Badania Ściskania Krat Lotniskowych z Tworzywa Sztucznego; Air Force Institute of Technology: Warsaw, Poland, 2020.

35. Standard NO-17-A500:2016 Airfield and Road Pavements—Road Capacity Testing; PKN: Warsaw, Poland, 2016.

36. Wesołowski, M.; Blacha, K. The impact of load bearing capacity of airfield pavement structures on the air traffic safety. In Proceedings of the Environmental Engineering 10th International Conference, Vilnius, Lithuania, 27-28 April 2017. [CrossRef]

37. Wesołowski, M.; Blacha, K.; Iwanowski, P. Analysis of load bearing capacity of cement concrete airfield pavement's construction in relation to its' changes of physico-mechanical parameters. IOP Conf. Ser. Mater. Sci. Eng. 2019, 603. [CrossRef] 
38. Rasol, M.; Perez-Gracia, V.; Fernandes, F.; Pais, J.C.; Solla, M.; Santos, C.R. NDT assessment of rigid pavement damages with ground penetrating radar: Laboratory and field tests. Int. J. Pavement Eng. 2020, 20. [CrossRef]

39. Wesołowski, M.; Pietruszewski, P.; Iwanowski, P. Analysis of natural airfield pavement load-bearing capacity in the aspect of air operation safety. In Proceedings of the 29th European Safety and Reliability Conference, Hannover, Germany, 22-26 September 2019; Beer, M., Zio, E., Eds.; Research Publishing: Singapore, 2019. [CrossRef]

40. Standard PN-EN ISO 1133-1:2011 Plastics_Determination of the Melt Mass-Flow Rate (MFR) and Melt Volume-Flow Rate (MVR) of Thermoplastics_Part 1: Standard Method; PKN: Warsaw, Poland, 2011.

41. Standard PN-EN ISO 1183-1:2019-05 Plastics-Methods for Determining the Density of Non-Cellular Plastics—Part 1: Immersion Method, Liquid Pycnometer Method and Titration Method; PKN: Warsaw, Poland, 2019.

42. Standard PN-EN ISO 527-2:+A1:2019-08 Plastics—Determination of Tensile Properties-Part 2: Test Conditions for Moulding and Extrusion Plastics; PKN: Warsaw, Poland, 2019.

43. Standard ISO 16770:2004 Plastics—Determination of Environmental Stress Cracking (ESC) of Polyethylene-Full-Notch Creep Test (FNCT); ISO: Geneva, Switzerland, 2004.

44. Standard PN-EN ISO 179-2:2020-12 Plastics—Determination of Charpy Impact Properties—Part 2: Instrumented Impact Test; PKN: Warsaw, Poland, 2020.

45. Standard PN-EN ISO 868:2005 Plastics and Ebonite-Determination of Indentation Hardness by Means of a Durometer (Shore Hardness); PKN: Warsaw, Poland, 2005.

46. Standard PN-EN ISO 2039-1:2004 Plastics_Determination of Hardness_Part 1: Ball Indentation Method; PKN: Warsaw, Poland, 2004.

47. Standard PN-EN ISO 306:2014-02 Plastics_Thermoplastic Materials_Determination of Vicat Softening Temperature (VST); PKN: Warsaw, Poland, 2014.

48. Wesołowski, M.; Kowalewska, A. The impact of a geogrid system on load-bearing capacity of natural airfield pavements. Arch. Civ. Eng. 2020. [CrossRef] 